\title{
Fluid-fluxed melting and melt loss in a syntectonic contact metamorphic aureole from the Variscan eastern Pyrenees
}

\begin{tabular}{|r|l|}
\hline Journal: & Journal of Metamorphic Geology \\
\hline Manuscript ID & JMG-15-0011.R4 \\
\hline Manuscript Type: & Original Article \\
\hline Complete List of Authors: & $\begin{array}{l}\text { Aguilar Gil, Carmen; Universidade Federal de Ouro Preto, Departamento de } \\
\text { Geologia; Universitat de Barcelona, Petrologia, Gequímica i Prospecció } \\
\text { Geològica } \\
\text { Liesa, Montserrat; Universitat de Barcelona, Geoquímica, Petrologia i } \\
\text { Prospecció Geològica } \\
\text { Reche, Joan; Universitat Autònoma de Barcelona, Departament de } \\
\text { Geologia } \\
\text { Powell, Roger; University of Melbourne, School of Earth Sciences }\end{array}$ \\
\hline Keywords: & $\begin{array}{l}\text { fluid-fluxed melting, melt loss, contact aureole migmatites, thermodynamic } \\
\text { modeling, Variscan Pyrenees }\end{array}$ \\
\hline &
\end{tabular}


Fluid-fluxed melting and melt loss in a syntectonic contact metamorphic aureole from the Variscan eastern Pyrenees

\section{C.AGUILAR*1,2, M. LIESA ${ }^{2}$, J. RECHE$^{3} \&$ R. POWELL ${ }^{4}$}

${ }^{1}$ Departamento de Geología, Universidade Federal de Ouro Preto, Campus Universitario Morro do Cruzeiro s/n,35400-000 Ouro Preto-MG,Brazil.carmenmaguilar@hotmail.com

${ }^{2}$ Departament de Geoquímica, Petrologia i Prospecció Geologica, Universitat de Barcelona, Zona Universitària de Pedralbes, 08028 Barcelona, Spain. mliesa@ub.edu

${ }^{3}$ Departament de Geologia, Universitat Autònoma de Barcelona, 08193 Bellaterra (Cerdanyola del Vallès), Barcelona, Spain.joan.reche@uab.cat

${ }^{4}$ School of Earth Sciences, The Univeristy of Melbourne, Vic 3010, Australia.powell@unimelb.edu.au

* Corresponding author

Telephone: +55 (31) 98560-2791

E-mail address: carmenmaguilar@hotmail.com (Carmen Aguilar)

Short title: Melting-rehydration events in an open system 


\begin{abstract}
Open-system behavior through fluid influx and melt loss can produce a variety of migmatite morphologies and mineral assemblages from the same protolith composition. This is shown by different types of granulite facies migmatite from the contact aureole of the Ceret gabbro-diorite stock in the Roc de Frausa Massif (eastern Pyrenees). Patch, stromatic and schollen migmatites are identified in the inner contact aureole, whereas schollen migmatites and residual melanosomes are found as xenoliths inside the gabbro-diorite. Patch and schollen migmatites record D1 and D2 structures in folded melanosome and mostly preserve the high-temperature D2 in granular or weakly foliated leucosome. Stromatic migmatites and residual melanosomes only preserve D2. The assemblage quartz-garnet-biotite-sillimanite-cordierite $\pm \mathrm{K}$-feldspar-plagioclase is present in patch and schollen migmatites, whereas stromatic migmatites and residual melanosomes contain a sub-assemblage with no sillimanite and/or K-feldspar. A decrease in $X_{\mathrm{Fe}}($ molar $\mathrm{Fe} /(\mathrm{Fe}+\mathrm{Mg}))$ in garnet, biotite and cordierite is observed from patch migmatites through schollen and stromatic migmatites to residual melanosomes. Whole-rock compositions of patch, schollen and stromatic migmatites are similar to those of non-migmatitic rocks from the surrounding area. These metasedimentary rocks are interpreted as the protoliths of the migmatites. A decrease in the silica content of migmatites from 63 to $40 \mathrm{wt} . \% \mathrm{SiO}_{2}$ is accompanied by an increase in $\mathrm{Al}_{2} \mathrm{O}_{3}$ and $\mathrm{MgO}+\mathrm{FeO}$ and by a depletion in alkalis. Thermodynamic modeling in the NCKFMASHTO system for the different types of migmatite provides peak metamorphic conditions $\sim 7-8 \mathrm{kbar}$ and $840^{\circ} \mathrm{C}$. A nearly isothermal decompression history down to $5.5 \mathrm{kbar}$ was followed by isobaric cooling from $840{ }^{\circ} \mathrm{C}$ through $690{ }^{\circ} \mathrm{C}$ to lower temperatures. The preservation of granulite facies assemblages and the variation in mineral assemblages and chemical composition can be modeled by ongoing $\mathrm{H}_{2} \mathrm{O}$-fluxed melting accompanied by melt loss. The fluids were probably released by the crystallizing gabbro-diorite, infiltrating the metasediments and fluxing melting. Release of fluids and melt loss were probably favored by coeval deformation (D2). The amount of melt remaining in the system varied considerably among the different types of migmatite. The whole-rock compositions of the samples, the modeled compositions of melts at the solidus at $5.5 \mathrm{kbar}$ and the residues show a good correlation.
\end{abstract}

Key words: fluid-fluxed melting; melt loss; contact aureole migmatites; thermodynamic modeling; Variscan Pyrenees. 


\section{INTRODUCTION}

Migmatites can occur in high-grade areas of low-pressure-high-temperature (LP-HT) metamorphic belts or core complexes, in large segments of exposed deep continental crust and in the inner part of contact metamorphic aureoles (Sawyer, 2008; Brown, 2012). In contact aureoles, melting will occur at high temperatures, depending on the amount of $\mathrm{H}_{2} \mathrm{O}$ available. The melt can remain in situ, migrate out of the system (melt loss) or be incorporated from elsewhere (melt gain). Movement of fluid and migration of a melt fraction to dilatant sites is sustained if tectonic deformation is coeval with partial melting or crystallization of the melt, particularly if strain is accommodated heterogeneously (McLellan, 1988; Barbey et al., 1990; Sawyer, 1991; Brown, 1994; Sawyer, 1994; Brown et al., 1995a,b; Rutter, 1997; Vanderhaeghe, 1999; Marchildon \& Brown, 2001). Thus, melt will be segregated and will contain a higher proportion of alkalis while the residuum will be richer in ferromagnesian minerals (e.g. Barbey, 1991). In this scenario, the retrograde evolution depends on the dehydration of the rock and on the degree of interaction between melt and residuum (Kriegsman \& Hensen, 1998; Waters, 2001; White \& Powell, 2002). If melt is lost before the onset of retrogression, high-temperature peak assemblages are preserved (Fyfe, 1973; Fyfe et al, 1978; Powell, 1983b; Guernina \& Sawyer, 2003). Conversely, if melt is available while the temperature drops, partial or total retrogression of high-temperature assemblages can take place (Powell, 1983a; Powell \& Downes, 1990; Spear et al., 1999; White et al., 2001; Brown, 2002; White \& Powell, 2002). Consequently, the composition of the rock systems may be heterogeneously modified, reflecting changes in mineral modes and assemblages ranging from typically original compositions to refractory residua. Thus, migmatites will experience different, albeit related, thermo-mechanical histories (Baldwin et al., 2005; White \& Powell, 2011).

During the past few decades, our knowledge of crustal melting, melt migration and extraction, and the evolution of granulite facies terranes has advanced considerably (e.g. Powell, 1983; Brown, 1994; Brown et al., 1999; Sawyer et al., 1999; White \& Powell, 2002; Hasalová et al., 2008a,b; Brown, 2012). Migmatites, melting and melt extraction have been studied through field and petrographic relationships (Brown et al., 1995a; Marchildon \& Brown, 2001; Sawyer, 2001; Hasalová et al., 2008a), and by experimental simulation using analogue models (Barraud et al., 2001, 2004; Druguet \& Carreras, 2006) and numerical modeling (Mackenzie, 1984; Vigneresse \& Burg, 2000; Simakin \& Petford, 2003). Early estimates of the amount of melt formed or lost relied mainly on geochemical and petrographic studies (e.g. Sawyer, 1987; Wickham, 1987; Barbey et al., 1996; Guernina \& Sawyer, 2003), whereas more recently phase equilibria modeling has been used with increasing frequency (White \& Powell, 2002; Korhonen et al., 2010).

The present paper involves study of a suite of migmatitic rocks cropping out in a low-pressure contact aureole in the Variscan eastern Pyrenees. The first part of the paper describes the variety of textures, mineral assemblages and whole-rock compositions of a set of samples occurring in close association with each other. Forward modeling of phase equilibria is used to infer the $P-T$ conditions of the last equilibration for the different types of migmatite. The second part models and evaluates the ability of various closed- and open-system processes to account for the different mineral assemblages and variations in mineral and whole-rock compositions recorded in the migmatites. In particular, we assessed the role of water in the melting process and estimated the amounts of melt gained or lost during cycles of the melt loss and 
rehydration and compared these with the amount of leucosome present in the migmatites.

\section{GEOLOGICAL SETTING AND FIELD RELATIONSHIPS}

Pre-Variscan and Variscan rocks crop out at the core of the Pyrenean Alpine belt (Axial Zone; Fig. 1a). The pre-Variscan rocks consist mainly of a metasedimentary sequence of upper Proterozoic to Carboniferous age with orthogneiss sheets, which mostly represent Ordovician granitic intrusions interlayered in the sequence. All these rocks were deformed and metamorphosed under LP-HT conditions in the Variscan orogeny. They were intruded at different crustal levels by a coeval to late-tectonic calc-alkaline suite of igneous rocks (Fig. 1a).

The Roc de Frausa Massif (Fig. 1b) is located in the eastern Pyrenees where the deepest structural and stratigraphic levels of the orogen crop out. The massif consists of a metasedimentary sequence that is dominated by upper Proterozoic to lower Cambrian metapelites and metagreywackes sporadically interbedded with layers of varied lithologies, including amphibolites, metatuffs, marbles, calc-silicates, quartzites and black shales, making up a lithologically complex unit. Two orthogneiss sheets divide the metasedimentary succession into three units (Upper, Intermediate and Lower series). These orthogneisses represent pre-Variscan granites intruded at $560 \pm 7 \mathrm{Ma}$ (Mas Blanc orthogneiss) and $476 \pm 5 \mathrm{Ma}$ (Roc de Frausa orthogneiss; Castiñeiras et al., 2008). The pre-Variscan rocks were affected by three deformation events (Liesa \& Carreras, 1989; Aguilar et al., 2015). The main deformation event (D1) is characterized by the development of a pervasive axial planar foliation (S1) associated with the formation of rootless and syn-schistose $\mathrm{F} 1$ isoclinal folds affecting the whole crustal section. Two later deformation events (D2 and D3) produced a fold interference pattern that resulted in the present structure of the massif (Fig. 1b). D2 is characterized by NE-SW-trending upright to tight folds that strongly folded $\mathrm{S} 1$ foliation at all scales. In high-strain domains, S1 is transposed by a steep (S2) foliation. D3 is recognized by NW-SEtrending open folds and by shear zones associated with them. A pervasive retrograde foliation developed in these shear zones transposing older structures. D1 and D2, which are attributed to the Variscan orogeny, are correlated with prograde metamorphism and are associated with the intrusion of igneous rocks. D3, which was formed under greenschist facies conditions, can be attributed to the Alpine cycle as indicated by the post-Variscan age obtained for the shear zones at the eastern end of the massif (El Portús, c. $38 \mathrm{Ma}$ by the ${ }^{40} \mathrm{Ar} /{ }^{39} \mathrm{Ar}$ method; Maurel, 2003).

The metasedimentary units and the orthogneisses preserve a continuous sequence of LP-HT metamorphism. In the metasedimentary units, andalusitesillimanite micaschists predominate in the Upper series, sillimanite schists in the Intermediate series and migmatites in the Lower series. Metamorphic conditions for the three metapelitic units were constrained by Aguilar et al. (2015). These authors assigned $P-T$ conditions $\sim 4.5-2.6 \mathrm{kbar}$ at $580-640{ }^{\circ} \mathrm{C}$ to the Upper series and $>4 \mathrm{kbar}$ at $620-660{ }^{\circ} \mathrm{C}$ to the Intermediate series coeval with the development of the $\mathrm{S} 1$ fabric. The late regional orogenic migmatites of the Lower series recorded the last $P-T$ history synchronous with decompression with temperatures from $>750{ }^{\circ} \mathrm{C}$ at $>5 \mathrm{kbar}$ to $700{ }^{\circ} \mathrm{C}$ at $\sim 3$ kbar. The age of Variscan regional metamorphism was estimated at $320 \pm 13 \mathrm{Ma}$ and $315 \pm 4 \mathrm{Ma}$ (conventional U-Pb zircon ages by SHRIMP-RG; Aguilar et al., 2014) in migmatites of the Lower series. The estimated $P-T$ paths were interpreted as clockwise marked by heating, possibly associated with increasing pressure during D1 
with a peak at 320-315 Ma followed by decompression coeval with the D2 event (Aguilar et al., 2015).

Two Variscan intrusions were emplaced at different levels of the series. A sheetlike tonalite-granite pluton $\left(150 \mathrm{~km}^{2}\right)$ was emplaced on top of the Upper series subparallel to $\mathrm{S} 1$. The pluton has mostly gradational contacts between the granite types and sharp contacts with the country rocks and includes scarce xenoliths near its border. A contact aureole approximately 500 meters wide developed around it, overprinting medium-grade regional metamorphism and forming hornfelses with sillimanitecordierite-bearing assemblages. Field relations indicate that this granite intruded during late-D1 and was dated by U-Pb zircon yielding an age c. $311 \mathrm{Ma}$ (Aguilar et al., 2014). The Ceret gabbro-diorite stock $\left(10 \mathrm{~km}^{2}\right)$ including ultramafic cumulates intruded mostly into the Intermediate series coeval with the D2 event (see column in Fig. 1b). The gabbro-diorite consists of a main body with meter-scale satellite intrusions scattered throughout the country rock within a radius of $2 \mathrm{~km}$. The gabbro is composed of plagioclase, clinopyroxene, amphibole (mostly hornblende) and biotite, and with minor amounts of altered olivine locally included in clinopyroxene and interstitial quartz. The texture grades from granular to ophitic with idiomorphic plagioclase embedded in clinopyroxene. Mafic minerals form a corona texture around olivine and clinopyroxene. Garnet is locally present near the contact with the metapelites and intergrows with biotite. Occasionally, it is surrounded by amphibole and biotite.

A number of xenoliths of the country rock comprising metapelites and refractory metamorphic country-rocks including marbles, amphibolites and calc-silicate rocks are included inside the gabbro. Metapelitic xenoliths are migmatitic and form rounded to irregular shaped bodies that vary in size from centimetric to decametric. Migmatites were also developed in the inner contact aureole $(250 \mathrm{~m})$ around the main intrusion. All migmatites have diffuse borders with the igneous rock and are mineralogically and texturally highly variable. The metamorphic conditions of the contact aureole migmatites were recently estimated by mineral equilibria modeling calculated for a MnO-bearing system (Mn-NCKFMASHTO; Aguilar et al., 2015), yielding $P-T$ conditions in the range $\sim 7.5$ to $\sim 4.8$ kbar at a temperature between 750 and $710{ }^{\circ} \mathrm{C}$.

$\mathrm{U}-\mathrm{Pb}$ geochronology of the gabbro-diorite Ceret stock gives an age c. $307 \mathrm{Ma}$ (Aguilar et al., 2014), constraining the age of the D2 event and the migmatization in the aureole. Moreover, a small number of leucogranitic bodies with two micas intruded at different crustal levels of the massif (Fig. 1b), which may be interpreted as the last event.

\section{PETROGRAPHIC AND STRUCTURAL FEATURES OF MIGMATITES}

Petrographic and meso- to microstructural studies were carried out in the migmatites affected by the Ceret gabbro-diorite contact aureole (Fig. 1b), summarized in Figs 2, 3 and 4. Following the migmatite terminology of Sawyer (2008), four types of migmatite (patch, schollen, stromatic, and residual melanosomes) can be distinguished on the basis of the structures observed at meso- and micro-scale. Patch, stromatic and schollen migmatites are present in the inner contact aureole, whereas schollen migmatites and residual melanosomes occur as xenoliths inside the gabbro-diorite.

The migmatites are interpreted to be composed of a neosome, which is normally segregated into leucosome and melt-depleted melanosome. Leucosome is dominated by quartz, plagioclase and less abundant K-feldspar. Melanosome generally contains 
biotite, sillimanite, cordierite and garnet. A fine-grained melanosome with a high proportion of sillimanite and biotite and a coarse-grained melanosome with dominant cordierite and garnet can be distinguished. Modal proportions within the assemblages also vary considerably. Sillimanite and/or K-feldspar are absent in stromatic migmatites and residual melanosomes. Accessory minerals include ilmenite, pyrite, apatite, zircon, monazite, rutile, tourmaline, and locally green or brown spinel and corundum. Spinel is normally included in cordierite or in prismatic sillimanite in all the migmatitic types except in patch migmatites, whereas corundum is only found within sillimanite in schollen migmatites.

Muscovite, chlorite and pinnite, and locally late andalusite are associated with low-temperature retrogression or with the last deformation event (D3; Fig. 3). Mineral abbreviations used are: q, quartz; g, garnet; bi, biotite; sill, sillimanite; cd, cordierite; pl, plagioclase; ksp, K-feldspar; ilm, ilmenite; and sp, spinel (Holland \& Powell, 1998).

\section{Patch migmatites}

Patch migmatites comprise fine-grained melanosome with scarce (up to $\sim 8$ vol.\%) coarse-grained leucosome (Fig. 2a). The melanosome consists of alternating layers of fibrolite and biotite presenting a planar fabric. The leucosome is composed of coarsegrained quartz, biotite, K-feldspar and plagioclase with a granoblastic to granular texture. Garnet and cordierite occur as porphyroblasts mostly in melanosome and locally in leucosome.

Patch migmatites are well-foliated rocks preserving two high temperature deformation events, D1 and D2 (Fig. 3). F2 folds are the most prominent feature. They fold S1 and locally develop an axial plane S2 foliation. Melanosome is parallel to the limbs of the F2 folds, whereas the small patches of leucosome are oriented either along $\mathrm{S} 1$, in F2 fold hinges, or more commonly along the S2 foliation (Fig. 2a,b). The S1 foliation is axial plane to tight F1 folds observed in the melanosome and is defined by oriented biotite-fibrolite-rich layers. The patches of leucosome have lenticular shapes and have diffuse limits with the melanosome; albeit locally, the limit with the melanosome is outlined by a narrow biotite-rich rim described as selvedges (Fig. 2b). Garnet porphyroblasts (up to $4.5 \mathrm{~mm}$ ) contain inclusion trails of fibrolite, biotite and ilmenite in their outer portion and are parallel to the S1 fabric (Fig. 2c). Thus, garnet grew over the S1 fabric in the presence of sillimanite and biotite. Cordierite poikiloblasts enclose all minerals of the assemblage that grow either parallel to the flanks of the folded S1 foliation or to the S2 fabric with no pressure shadows around them (Fig. 2d). Therefore, cordierite is interpreted as growing late- to post-D2.

\section{Stromatic migmatites}

Stromatic migmatites comprise well-foliated fine-grained melanosome alternating with coarse-grained leucosome (Fig. 2e). Both leucosome and melanosome are regularly spaced and are parallel to S2 foliation (Fig. 3). Melanosome also occurs as rootless folds with axial planes parallel to S2. Leucosome ( 40 vol.\%) is composed of quartz and plagioclase with an anhedral to subhedral granular texture. Garnet occurs as porphyroblasts (up to $5 \mathrm{~mm}$ ) along the boundary between the leucosome and melanosome or inside the leucosome (Fig. 2f). They are corroded and partially replaced by coarse-grained biotite, plagioclase or cordierite. Melanosome ( $\sim 60 \mathrm{vol} . \%)$ is composed of cordierite and abundant biotite, which occurs parallel to the S2 foliation or as unoriented plates mimicking S2. Cordierite encloses biotite and green spinel (Fig. 2f) and no S2 pressure shadows are developed around it. Cordierite is therefore interpreted 
as late- to post-D2 event. Sillimanite is rare in the melanosome and is parallel to a composite $\mathrm{S} 1 / \mathrm{S} 2$ fabric.

\section{Schollen migmatites}

Schollen migmatites have more leucosome than patch migmatites ( $\sim 38$ vol.\%) although melanosome dominates the structure of the rock $(\sim 62 \mathrm{vol} . \%)$. Rafts of elongated, finegrained melanosome are embedded in coarse-grained leucosome mostly parallel to S2 or to shear bands forming a net structure (Fig. 4a,b). In leucosome-rich domains, these melanosome rafts are either parallel to F2 axial planes, rotated or boudinaged and leucosome occupies the spaces between melanosome. In low strain domains, rafts preserve the $\mathrm{S} 1$ foliation and syn-schistose $\mathrm{F} 1$ isoclinal folds that are defined by fibrolitic sillimanite (Figs $3 \&$ 4a,b). In high strain domains, S2 foliation almost transposes the previous fabric. Narrow selvedges consisting mostly of biotite occur at the boundary of the leucosome.

Melanosome is formed by layers of fibrolite and biotite with a foliated microstructure. Coarse-grained biotite, quartz and plagioclase with a granoblastic to granular texture are part of the leucosome. Prismatic sillimanite (about $10 \mathrm{~mm}$ long) is mainly present in the leucosome. However, in the melanosome it locally contains inclusion trails of ilmenite and biotite parallel to the S1 fabric. Prismatic sillimanite can grow parallel to the $\mathrm{S} 2$ fabric with pressure shadows or in radiating clusters, indicating syn- to late-D2 crystallization (Fig. 4c). Garnet porphyroblasts (up to $5.5 \mathrm{~mm}$ ) are bounded by pressure shadows aligned parallel to S2, indicating that D2 deformation developed after garnet growth. Cordierite occurs as poikiloblasts (up to 3-6 $\mathrm{mm}$ ) in the melanosome and the leucosome. It forms coronas around garnet and is interpreted to be late- to post-D2 (Fig. 4d). Plagioclase is microperthitic and forms euhedral to subhedral porphyroblasts (up to $2 \mathrm{~mm}$ ) in the leucosome, whereas K-feldspar may be absent or forms blebs included in plagioclase. Green or brown spinel and corundum are enclosed in cordierite and prismatic sillimanite.

\section{Residual melanosomes}

The residual melanosomes are massive rocks comprising $>95$ vol.\% melanosome (Fig. $4 \mathrm{e}$ ), which is composed of garnet porphyroblasts (up to $10 \mathrm{~mm}$ ) embedded in a cordierite-rich matrix with scarce biotite, plagioclase and quartz (Fig. 4f). Garnet is subhedral with embayments replaced by plagioclase and platy biotite, whereas twinned cordierite is anhedral. Biotite and ilmenite define a weak S2 foliation in the matrix and in cordierite (Figs $3 \& 4 \mathrm{e}, \mathrm{f}$ ). The weak S2 foliation and the granoblastic texture of cordierite suggest either that these residual melanosomes record a shorter deformation history than the migmatites or that they were thoroughly recrystallized during melt loss.

K-feldspar is absent, sillimanite (fibrolite) only occurs as inclusions in some garnets and scarce quartz (around 2\% modal) is found in interstices between cordierite. Plagioclase forms euhedral to subhedral porphyroblasts (up to $2 \mathrm{~mm}$ ), locally around garnet together with biotite. Brown spinel is always included in cordierite.

\section{MINERAL CHEMISTRY}

Samples corresponding to the four types of migmatite from the Ceret contact aureole and to non-migmatitic rocks from the Upper and Intermediate series of the massif were selected for mineral analysis at the Centres Científics i Tecnològics (CCiT) of the Universitat de Barcelona, using a Cameca SX-50 electron microprobe with wavelengthdispersive spectrometer in point beam mode at $15 \mathrm{nA}$ and $20 \mathrm{kV}$, and a $10 \mu \mathrm{m}$ beam 
diameter. Representative mineral analyses are summarized in Table S1 and shown in Figs $\mathrm{S} 1$ and 5. Abbreviations used for mineral end-members in molar proportions are $\mathrm{alm}=\mathrm{Fe} /(\mathrm{Ca}+\mathrm{Fe}+\mathrm{Mg}+\mathrm{Mn}), \mathrm{prp}=\mathrm{Mg} /(\mathrm{Ca}+\mathrm{Fe}+\mathrm{Mg}+\mathrm{Mn})$, grs $=\mathrm{Ca} /(\mathrm{Ca}+\mathrm{Fe}$ $+\mathrm{Mg}+\mathrm{Mn}), \mathrm{sps}=\mathrm{Mn} /(\mathrm{Ca}+\mathrm{Fe}+\mathrm{Mg}+\mathrm{Mn})$ and $X_{\mathrm{Fe}}(\mathrm{g}, \mathrm{bi}, \mathrm{cd})=\mathrm{Fe} /(\mathrm{Fe}+\mathrm{Mg})$. The sign " $\rightarrow$ " indicates a trend in mineral composition or zoning, the sign "-" depicts a range of mineral compositions and p.f.u. is per formula unit. The mineral chemistry of garnet, biotite and cordierite displays systematic changes through assemblages in the different structural migmatite types (Table S1).

\section{Garnet}

Garnet has flat compositional profiles near the cores, but systematically displays zoning near the rims (see Fig. S1 in "Supporting Information"). In patch and stromatic migmatites, almandine, spessartine and $X_{\mathrm{Fe}}$ increase, pyrope decreases and grossular remains constant towards the rim. A more complex pattern is identified in schollen migmatites and in residual melanosomes. In these rocks, garnet shows a slight increase in pyrope and a decrease in almandine, spessartine and $X_{\mathrm{Fe}}$ from cores to intermediate core-rim points followed by an increase in almandine, spessartine and $X_{\mathrm{Fe}}$, and by a decrease in grossular and pyrope at the outermost rims. Representative garnet compositions are $\operatorname{alm}_{77 \rightarrow 83} ; \operatorname{prp}_{15 \rightarrow 9} ;$ grs $_{4} ; \mathrm{sps}_{4} ; X_{\mathrm{Fe}}=0.84 \rightarrow 0.90$ for patch migmatites (sample 526, Fig. S1a); $\operatorname{alm}_{66 \rightarrow 76} ;$ prp $_{26 \rightarrow 14} ;$ grs $_{4} ; \operatorname{sps}_{4 \rightarrow 7} ; X_{\mathrm{Fe}}=0.72 \rightarrow 0.84$ for stromatic migmatites (sample 529, Fig. S1b); alm $\lim _{83 \rightarrow 78 \rightarrow 81} ; \operatorname{prp}_{5 \rightarrow 13 \rightarrow 9} ; \operatorname{grs}_{7 \rightarrow 4} ; \mathrm{sps}_{6 \rightarrow 4 \rightarrow 7} ; X_{\mathrm{Fe}}=$ $0.95 \rightarrow 0.86 \rightarrow 0.90$ for schollen migmatites (sample 459, Fig. S1c) and $\operatorname{alm}_{72 \rightarrow 69 \rightarrow 70}$; prp $_{22 \rightarrow 26 \rightarrow 25} ;$ grs $_{3} ; \mathrm{sps}_{2 \rightarrow 1} ; X_{\mathrm{Fe}}=0.76 \rightarrow 0.72 \rightarrow 0.74$ for residual melanosomes (sample 462, Fig. S1d).

\section{Biotite}

The composition of matrix biotite from the melanosome in patch migmatites (sample $526)$ is similar to that of biotite included in garnet $\left(X_{\mathrm{Fe}}=0.53-0.65\right.$ and $\mathrm{Ti}=0.13-0.30$ p.f.u.). In stromatic migmatites (sample 529), biotite has $X_{\mathrm{Fe}}=0.43-0.47$ and $\mathrm{Ti}=0.12-$ 0.21 p.f.u. In schollen migmatites (sample 459), biotite contains $X_{\mathrm{Fe}}=0.50-0.59$ and $\mathrm{Ti}$ $=0.10-0.26$ p.f.u. and similar compositions in melanosome and leucosome. Finally, in residual melanosomes (sample 462), biotite from the matrix has $X_{\mathrm{Fe}}=0.42-0.55$ and Ti $=0.05-0.28$ p.f.u.

\section{Cordierite}

Cordierite poikiloblasts are compositionally homogeneous. In patch migmatites they have an $X_{\mathrm{Fe}}=0.38-0.48$, whereas in stromatic migmatites they have an $X_{\mathrm{Fe}}=0.29-0.32$. Values between $0.35-0.42$ are typical of schollen migmatites and fairly constant values $\left(X_{\mathrm{Fe}}=0.33-0.35\right)$ are measured in residual melanosomes.

A positive correlation is found between $X_{\mathrm{Fe}}$ values of biotite and cordierite in the different types of migmatite (Fig. 5a). Non-migmatitic rocks (gray circle in Fig. 5a) present a high concentration and a wide $X_{\mathrm{Fe}}$ compositional range in biotite $\left(X_{\mathrm{Fe}}=0.48\right.$ to $0.63)$ and in cordierite $\left(X_{\mathrm{Fe}}=0.41\right.$ to 0.47$)$. In migmatites, the highest $X_{\mathrm{Fe}}$ values $\left(X_{\mathrm{Fe}}{ }^{\mathrm{bi}}=\right.$ $0.53-0.65$ and $\left.X_{\mathrm{Fe}}{ }^{\text {cd }}=0.38-0.48\right)$ correspond to patch migmatites. These values overlap or are higher than those of non-migmatitic rocks. The lowest $X_{\mathrm{Fe}}$ values correspond to stromatic migmatites $\left(X_{\mathrm{Fe}}{ }^{\mathrm{bi}}=0.43-0.47\right.$ and $\left.X_{\mathrm{Fe}}{ }^{\mathrm{cd}}=0.29-0.32\right)$. This correlation is also shared by garnet (Fig. $5 \mathrm{~b}$ ). Comparison of the composition of coexisting garnet, biotite and cordierite of the four types of migmatite reveals a progressive enrichment in $\mathrm{MgO}$ from patch to schollen migmatites, residual melanosomes and stromatic migmatites (Fig. 5b). An increase in the $\mathrm{Al}_{2} \mathrm{O}_{3}$ content of biotite is identified towards residual 
melanosomes, though this tendency is not shared by stromatic migmatites. This enrichment in $\mathrm{MgO}$ and $\mathrm{Al}_{2} \mathrm{O}_{3}$ is consistent with the change in the whole-rock composition of the samples (black symbols in Fig. 5b).

\section{WHOLE-ROCK COMPOSITION}

Samples collected in the field included migmatites (mixed leucosomes and melanosomes) and non-migmatitic rocks of the Upper and Intermediate series. The samples consisted of approximately $15-17 \mathrm{~kg}$ of rock, i.e. enough to be representative of the whole-rock composition. They were crushed and split to obtain representative fractions and pulverized in a tungsten-carbide mill. Whole-rock major-element analysis was carried out on the X-ray Fluorescence Spectrometer at the Centres Científics i Tecnològics (CCiT) of the Universitat de Barcelona. Analyses in weight percent (wt.\%) are summarized in Table S2 and presented in a series of Harker plots in Fig. 6 to show the geochemical variations.

The compositions of non-migmatitic and migmatitic rocks are equivalent to average shales, with high $\mathrm{K}_{2} \mathrm{O} / \mathrm{Na}_{2} \mathrm{O}$ and $\mathrm{FeO}+\mathrm{MgO}$ in contrast to typical greywackes (Taylor \& McLennan, 1985); the migmatites are strongly peraluminous (Sylvester, 1998). The $\mathrm{CaO} / \mathrm{Na}_{2} \mathrm{O}$ ratio in migmatites tends to be higher than in non-migmatitic rocks although it is very variable in stromatic migmatites (Table S2). A/AFM is higher and more variable in non-migmatitic rocks than in migmatites. Values of $X_{\mathrm{Si}}$ $\left(\mathrm{SiO}_{2} /\left(\mathrm{SiO}_{2}+\mathrm{Al}_{2} \mathrm{O}_{3}+\mathrm{FeO}+\mathrm{MgO}\right)\right)$ and $X_{\mathrm{Fe}}(\mathrm{FeO} /(\mathrm{FeO}+\mathrm{MgO}))$ are similar to shales and lower in migmatites than in non-migmatites, consistent with changes occurred during increasing metamorphic grade (Ague, 1991).

Systematic changes in major element composition of the migmatites are shown in Fig. 6. The $\mathrm{SiO}_{2}$ content of migmatites is 50 to $63 \mathrm{wt} . \%$, whereas for non-migmatitic rocks (shaded area in Fig. 6), whose composition is assumed to be similar to that of the protoliths, is 55 to $63 \mathrm{wt} . \%$. $\mathrm{SiO}_{2}$ tends to be higher in stromatic migmatites, lower in patch and schollen migmatites, and decreases to $\sim 40 \mathrm{wt} . \%$ in residual rocks. In general, $\mathrm{Al}_{2} \mathrm{O}_{3}, \mathrm{FeOt}$ and $\mathrm{MgO}$, and to a minor extent $\mathrm{TiO}_{2}$ show an inverse correlation with $\mathrm{SiO}_{2}$. $\mathrm{CaO}, \mathrm{Na}_{2} \mathrm{O}$ and $\mathrm{K}_{2} \mathrm{O}$ values are scattered in migmatites but less variable in nonmigmatites; there is no clear correlation with $\mathrm{SiO}_{2}$. Values of $\mathrm{P}_{2} \mathrm{O}_{5}$ have a roughly positive correlation with $\mathrm{SiO}_{2}$. The more variable content of the major element oxides in migmatites with respect to non-migmatitic rocks indicates that partial melting was an open-system process. The negative correlation in $\mathrm{Al}_{2} \mathrm{O}_{3}, \mathrm{FeOt}, \mathrm{MgO}$ and $\mathrm{TiO}_{2}$ versus $\mathrm{SiO}_{2}$ suggests residual enrichment in these oxides in the migmatites caused by the removal of other oxides, as suggested by Ague (1991). Conversely, the variability of $\mathrm{Na}_{2} \mathrm{O}, \mathrm{K}_{2} \mathrm{O}$ and $\mathrm{CaO}$ with respect to $\mathrm{SiO}_{2}$ suggests mobility of these elements during partial melting.

\section{FORWARD MODELING OF MIGMATITES}

The aim of this section is to assess the ability of various closed- and open-system processes to account for the different mineral assemblages and variations in mineral and whole-rock compositions recorded in the migmatites. To achieve this, forward modeling of phase equilibria in a closed system is used to infer the $P-T$ conditions of the last equilibration for the different types of migmatite. Then an average pressure is fixed to allow the forward modeling of open-system processes that are interpreted to have led to the final product. This then allows an estimation of the amount of melt gained or lost during metamorphism so it can be compared with the migmatites. 


\section{Calculation methods}

The $P-T$ and $T-X$ pseudosections were calculated using THERMOCALC 3.35 (Powell et al., 1998; update 2010) and the DATASET 5.5 (Holland \& Powell, 1998; November 2003 upgrade) in the system $\mathrm{Na}_{2} \mathrm{O}-\mathrm{CaO}-\mathrm{K}_{2} \mathrm{O}-\mathrm{FeO}-\mathrm{MgO}-\mathrm{Al}_{2} \mathrm{O}_{3}-\mathrm{SiO}_{2}-\mathrm{H}_{2} \mathrm{O}-\mathrm{TiO}_{2}-\mathrm{O}_{2}$. The activity-composition $(a-x)$ models are from the THERMOCALC file (compiled 28/12/07), where the cordierite and staurolite models are from Holland \& Powell (1998) and garnet, biotite and silicate melt models from White et al. (2007). Muscovite is from Coggon \& Holland (2002), feldspars from Holland \& Powell (2003), orthopyroxene, spinel and magnetite from White et al. (2002), and ilmenite, hematite and alternate model of magnetite for low-grade rocks from White et al. (2000). Rock compositions were used with the molar amounts of the oxides normalized to $100 \%$.

The amount of $\mathrm{H}_{2} \mathrm{O}$ in the whole-rock composition was deduced from $T$ $M\left(\mathrm{H}_{2} \mathrm{O}\right)$ pseudosections at a pressure of $5.5 \mathrm{kbar}$, adjusting the minimum amount of $\mathrm{H}_{2} \mathrm{O}$ to be added to the sample so that the first partial melting took place at the minimum temperature to account for the preserved mineral assemblages, mineral composition and mode variations (see White et al., 2002 for an example of this approach). Moreover, the water content of the pseudosections is comparable to the LOI value obtained for the corresponding analyses. The amount of $\mathrm{Fe}_{2} \mathrm{O}_{3}$ for the calculations was set in such a way that the modeled mineral assemblages contained magnetite or not in agreement with the observed assemblages. Pseudosections were contoured for both mineral compositions and modes for the phases of interest, providing additional constraints on $P-T$ variations. The isopleth notation used is $x_{\mathrm{Fe}}(\mathrm{bi}, \mathrm{cd}, \mathrm{g})=\mathrm{Fe} /(\mathrm{Fe}+$ $\mathrm{Mg}$ ) and molar proportions (mol.\%) of spinel or sillimanite, and garnet, cordierite and liquid.

\section{Closed system mineral equilibria modeling in the NCKFMASHTO system}

The $P-T$ path for the four migmatite types (patch, stromatic and schollen migmatite, and a residual melanosome) was determined assuming a single episode of partial melting, as deduced from the $P-T$ conditions of the neighboring rocks unaffected by the gabbrodiorite contact aureole (see Aguilar et al., 2015). Thus, all metapelites would be heated from subsolidus water-saturated conditions and immediately above the solidus free $\mathrm{H}_{2} \mathrm{O}$ would be strongly partitioned into the new silicate melt phase. The last pressure equilibration conditions of all migmatite types was assumed to be similar because (i) the rock samples were located in the inner contact aureole or as xenoliths inside the gabbro-diorite around $1 \mathrm{~km}$ away from each other; and (ii) they occurred in close association with each other during the metamorphic processes (regional metamorphism followed by contact metamorphism) in the absence of major tectonic discontinuities. The main features and topology of the pseudosections for the patch and the schollen migmatites are similar, whereas those of the stromatic migmatite and the residual melanosome are different from each other (Figs S2 to S5).

\section{Patch migmatites: pseudosection for sample 526}

The reaction sequence for sample 526 is compatible with a prograde path marked by a decrease in the mineral mode of sillimanite along with an increase in garnet since their modal isopleths are sub-parallel in the q-g-bi-sill \pm ksp-liq fields at $\sim 7-8 \mathrm{kbar}$ (Fig. S2). A consistent $P-T$ path for the presence of cordierite poikiloblasts involves a pressure decrease from $\sim 7-8 \mathrm{kbar}$ to $\sim 5.5 \mathrm{kbar}$ in the q-g-bi-sill-cd-liq field and a temperature decrease from $850{ }^{\circ} \mathrm{C}$ to $720^{\circ} \mathrm{C}$. The high-pressure side of this field is limited by the cordierite-out line and the low-pressure side by the garnet-out line (Fig. S2a). The scarcity of garnet and its corroded edges in the preserved mineral assemblage is 
resolved in the pseudosection by its molar proportion decreasing during decompression and cooling (Fig. S2b). The assemblage q-g-bi-sill-cd was probably preserved when the rock crossed the solidus at $\sim 5.5 \mathrm{kbar}$ and $720^{\circ} \mathrm{C}$. The calculated isopleths for garnet, biotite and cordierite (Fig. S2c-e) indicate $X_{\mathrm{Fe}}$ enrichment after a fall in temperature between 5.5-5 kbar. This tendency is also indicated by the corresponding analyzed mineral compositions. The values of biotite $\left(X_{\mathrm{Fe}}=0.53-0.65\right)$ and cordierite $\left(X_{\mathrm{Fe}}=0.38-0.48\right)$ closely match those defined by the isopleths. Conversely, garnet $X_{\mathrm{Fe}}$ values for mineral analyses $\left(X_{\mathrm{Fe}}=0.84 \rightarrow 0.90\right.$; from core to rim) are richer in Fe than the garnet isopleths, suggesting garnet re-equilibration under subsolidus conditions. In summary, the path inferred by these microstructural relations involves a pressure decrease from $\sim 7-8 \mathrm{kbar}$ to $\sim 5.5 \mathrm{kbar}$ followed by a fall in temperature from $850{ }^{\circ} \mathrm{C}$ to $720{ }^{\circ} \mathrm{C}$ (Fig. 7).

\section{Stromatic migmatites: pseudosection for sample 529}

The most important petrographic characteristic of sample 529 is the presence of cordierite poikiloblasts including biotite and green spinel, and with no pressure shadows. In the pseudosection (Fig. S3a), the formation of green spinel may be attributed to a fall in pressure from the q-g-bi-cd-liq field to the q-g-bi-cd-liq-sp field, implying an increase in the mode of cordierite and a decrease in garnet content (Fig. S3b). In the q-g-bi-cd-liq-sp field, the calculated isopleths (Fig. S3c-e) indicate $X_{\mathrm{Fe}}$ enrichment after a drop in temperature at $\sim 5 \mathrm{kbar}$. These values are similar to the mineral compositions of garnet $\left(X_{\mathrm{Fe}}\right.$ (core to rim) $\left.=0.72 \rightarrow 0.84\right)$, biotite $\left(X_{\mathrm{Fe}}=\right.$ $0.43-0.47)$ and cordierite $\left(X_{\mathrm{Fe}}=0.29-0.32\right)$. In the pseudosection, these compositions are located close to the solidus at $\sim 5 \mathrm{kbar}$ and $720^{\circ} \mathrm{C}$. Thus, the complete path involves a pressure decrease from $\sim 6-7 \mathrm{kbar}$ to $\sim 5 \mathrm{kbar}$ followed by a drop in temperature from $800{ }^{\circ} \mathrm{C}$ to $720{ }^{\circ} \mathrm{C}$ (Fig. 7).

\section{Schollen migmatites: pseudosection for sample 459}

In this sample the presence of cordierite poikiloblasts with no pressure shadows that includes an earlier mineral assemblages indicates a nearly isothermal decompression path from the q-g-bi-sill-ksp-liq field to the q-g-bi-sill-cd-ksp-liq field (Fig. S4a). The late crystallization of prismatic sillimanite and the presence of K-feldspar blebs included in euhedral porphyroblasts of plagioclase are attributed in the pseudosection to an increase in the molar proportion of sillimanite with decreasing temperature towards the q-g-bi-sill-cd-liq field and to the destabilization of K-feldspar (Fig. S4b). The path would end at the solidus at $\sim 5 \mathrm{kbar}$ and $690^{\circ} \mathrm{C}$. This regressive path is also recorded by the $X_{\mathrm{Fe}}$ enrichment of ferromagnesian minerals. The $X_{\mathrm{Fe}}$ of the analyzed garnet is homogeneous and higher $\left(X_{\mathrm{Fe}}=0.95 \rightarrow 0.86 \rightarrow 0.90\right.$; core to rim and outermost rim $)$ than that of the calculated isopleths for the same field (Fig. S4c), which strongly suggests further retrogression of garnet in the subsolidus field at lower temperatures. Conversely, the measured compositions of biotite $\left(X_{\mathrm{Fe}}=0.50-0.59\right)$ and cordierite $\left(X_{\mathrm{Fe}}=0.35-0.42\right)$ are roughly within the range of calculated isopleths in the q-g-bi-sill-cd-liq field (Fig. S4d-e). In summary, the path inferred by these microstructural relations involves a pressure decrease from $\sim 7-8 \mathrm{kbar}$ to $\sim 5 \mathrm{kbar}$ followed by a drop in temperature from $840{ }^{\circ} \mathrm{C}$ to $690{ }^{\circ} \mathrm{C}$ (Fig. 7).

\section{Residual melanosomes: pseudosection for sample 462}

The presence of spinel indicates that the rock attained a temperature $>780{ }^{\circ} \mathrm{C}$ in the $\mathrm{g}_{-}$ bi-cd-liq-sp field, where both spinel and cordierite would be stable but not quartz (Fig. S5a). On cooling, spinel would become unstable remaining as a relict phase and quartz would crystallize. The presence of thin quartz coronas around garnet and its interstitial 
habit (Fig. 4f) is attributed in the pseudosection to a decrease in temperature from $\sim 820$ ${ }^{\circ} \mathrm{C}$ to the solidus at $700{ }^{\circ} \mathrm{C}$ at $\sim 5.5 \mathrm{kbar}$. The calculated isopleths for this path (garnet, biotite and cordierite; Fig. S5c-e) are within the range of the analyzed mineral compositions (garnet $X_{\mathrm{Fe}}=0.76 \rightarrow 0.72 \rightarrow 0.74$; core to rim and outermost rim, biotite $X_{\mathrm{Fe}}$ $=0.42-0.55$ and cordierite $\left.X_{\mathrm{Fe}}=0.33-0.35\right)$. An isobaric retrograde path from $\sim 820{ }^{\circ} \mathrm{C}$ to $700{ }^{\circ} \mathrm{C}$ at $\sim 5.5 \mathrm{kbar}$ is interpreted for the residue (Fig. 7).

\section{Modeling open-system processes in the NCKFMASHTO system}

During the evolution of migmatitic complexes, either closed-system behavior (e.g. Sawyer, 1998; Milord et al., 2001) or open-system processes may occur (e.g. Olsen, 1982; Powell \& Downes, 1990; White \& Powell, 2002; Hasalová et al., 2008a,b; Yakymchuk \& Brown, 2014). In the Roc de Frausa Massif, the strong variation in the whole-rock composition for the different types of migmatite and $\mathrm{CaO} / \mathrm{Na}_{2} \mathrm{O}$ ratio (see Table S2 and Fig. 6) suggests that open-system processes may have operated during contact metamorphism. The water released by hydrous magmas may enhance fluidfluxed melting of the country rock as happens in many contact aureoles (Pattison \& Harte, 1988; Johnson et al., 2003; Droop \& Brodie, 2012). This probably took place at the top of the crystallizing hydrous gabbro-dioritic stock that contains hornblende and biotite. Moreover, the irregular distribution of leucosome and restite-enriched domains points to segregation of the melt from the refractory phases (Olsen, 1982, 1984).

Given that open-system processes may have operated, the whole-rock composition of the migmatites may not correspond to that of an original protolith. Accordingly, a model composition was constructed using the average composition of several non-migmatitic rocks from the Upper and Intermediate series unaffected by the gabbro-diorite contact aureole (Table S2). To check whether the different assemblages preserved in the migmatites may derive from a common protolith through closed- or open-system processes and the influence of water in the melting system, we undertook forward modeling in the NCKFMASTHO system at the final equilibration pressure of 5.5 kbar (Fig. 7). We modeled three scenarios: (1) Dehydration melting in a system open to melt migration but closed to fluid infiltration (Fig. 8); (2) Fluid-present melting in a system closed to melt (Fig. 9); and (3) Fluid-present melting in a system open to fluid and melt in the presence of multiple melt-loss-rehydration events (Fig. 10).

Because the composition of melt within a rock changes with the temperature, a maximum temperature of $790{ }^{\circ} \mathrm{C}$, which is similar to the maximum achieved by all samples (Fig. 7), was fixed by $P-T$ pseudosection calculated for the hypothetical protolith initially containing $5.35 \mathrm{~mol} . \% \mathrm{H}_{2} \mathrm{O}$ (Fig. S6). The estimated fluid content of the protolith should be between 5.35 and $8 \mathrm{~mol} . \% \mathrm{H}_{2} \mathrm{O}$, according to the minimum amount of water required for a minimum melting temperature and the corresponding LOI values of the analyses of non-migmatitic rocks unaffected by the gabbro-diorite contact aureole (see Fig. 9). The $P-T$ diagram shows that, at a pressure of $5.5 \mathrm{kbar}$ and $790{ }^{\circ} \mathrm{C}$, the assemblage q-g-bi-sill-cd-ksp-liq that is observed in patch and schollen migmatites contains around 14 mol.\% melt (gray circle in Fig. S6).

Dehydration melting in a system open to melt migration but closed to fluid infiltration A $T-X_{\text {melt }}$ diagram was calculated at $5.5 \mathrm{kbar}$ to display the effect of melt loss from the system or melt redistribution within the system on the evolution of the phase assemblage during cooling. Consider a protolith heated from water-saturated subsolidus conditions to $790{ }^{\circ} \mathrm{C}$, by which point 14 mol. $\%$ melt has been produced (gray circle in Fig. 8). If the whole melt batch is removed from the equilibration volume, the rock will 
follow an isobaric and isothermal path until it reaches the solidus (green star in Fig. 8). At this point, the stable modeled assemblage (q-g-bi-sill-cd-ksp) will correspond to that of the melanosome in the patch and schollen migmatites and will be preserved after cooling. If instead only a proportion of the melt batch generated at $790{ }^{\circ} \mathrm{C}$ is lost from system (e.g. $8 \mathrm{~mol} \%$, leaving $6 \mathrm{~mol} \%$ ), the assemblage will evolve from q-g-bi-sillcd-ksp-liq to q-bi-sill-ksp on the cooling path (arrow A; Fig. 8). In this case the rock will reach the solidus around $690^{\circ} \mathrm{C}$ and the q-bi-sill-ksp assemblage will be preserved with a small amount of leucosome and small retrogression of garnet and cordierite. This preserved assemblage does not correspond to any of the migmatites. Conversely, if melt distributes heterogeneously, some domains may gain melt. As illustrated by arrow B in Fig. 8, a system in this circumstance will crystallize to upper amphibolite facies assemblages below $690{ }^{\circ} \mathrm{C}$.

In summary, dehydration melting in a system open to melt explains the preservation of the assemblages of patch and schollen migmatites only if melt is completely segregated from the melanosome, but it does not explain either the amount of leucosome present in schollen and stromatic migmatites or the assemblages present. Furthermore, it will not explain the depleted composition of the residual melanosomes. Therefore, a system open to water is needed.

\section{Fluid-present melting in a system closed to melt}

To test the influence of fluid in the melting system, a $T-M\left(\mathrm{H}_{2} \mathrm{O}\right)$ pseudosection was constructed at a fixed pressure of $5.5 \mathrm{kbar}$ for the same hypothetical protolith. This pseudosection illustrates the addition of up to $20 \mathrm{~mol} . \% \mathrm{H}_{2} \mathrm{O}$ to the anhydrous protolith, which yields a maximum amount of melt of $\sim 70$ mol.\% (Fig. 9). For this $M\left(\mathrm{H}_{2} \mathrm{O}\right)$ range, the stability field of the assemblage q-g-bi-sill-cd-ksp-liq present in patch and schollen migmatites is constrained to a narrow temperature window at $\sim 790{ }^{\circ} \mathrm{C}$. On the high-temperature side, this mineral assemblage is limited by the sillimanite-out line and on the low-temperature side by the cordierite-out line (Fig. 9). If fluid infiltration takes place in the system at $790{ }^{\circ} \mathrm{C}$, the path followed by the rocks will be represented by the black arrow in Fig. 9.

With $\mathrm{H}_{2} \mathrm{O}$-fluxed melting, $\mathrm{K}$-feldspar, sillimanite and quartz will be gradually consumed and the melt proportion will increase from 0 up to 60 mol.\% melt. For $M\left(\mathrm{H}_{2} \mathrm{O}\right)$ values between 5.35-7 mol.\% $\mathrm{H}_{2} \mathrm{O}(14-25 \mathrm{~mol} . \%$ melt $)$ and at a temperature near $790{ }^{\circ} \mathrm{C}$, the q-g-bi-sill-cd-ksp-liq assemblage of patch and schollen migmatites will be reproduced. At this temperature and $7 \mathrm{~mol} . \% \mathrm{H}_{2} \mathrm{O}$, the $\mathrm{K}$-feldspar-out line is crossed and the q-g-bi-sill-cd-liq assemblage that corresponds to that of schollen migmatites would be encountered up to 12.5 mol.\% $\mathrm{H}_{2} \mathrm{O}$ (15-55 mol.\% melt). The sillimanite-out line and the quartz-out line are crossed at temperatures above $760{ }^{\circ} \mathrm{C}$ and water content exceeding $11 \mathrm{~mol} . \%$. As a result, the assemblages $\mathrm{q}-\mathrm{g}-\mathrm{bi}-\mathrm{cd}-\mathrm{liq}$ corresponding to stromatic migmatites and $\mathrm{g}-\mathrm{bi}-\mathrm{cd}-\mathrm{liq}$ from residual melanosomes would be stabilized.

Assuming equilibrium, a major issue is that the peak assemblages of all types of migmatite will be replaced by a muscovite-sillimanite-biotite assemblage by reaction with melt down to the solidus $\left(\sim 660^{\circ} \mathrm{C}\right)$, releasing different proportions of $\mathrm{H}_{2} \mathrm{O}$ (vertical arrows in Fig. 9). In all cases, the conversion of the granulite facies assemblages to upper amphibolite would occur below $710-770{ }^{\circ} \mathrm{C}$ when the migmatites contain approximately between $20-60$ mol.\% melt. A large amount of melt retained in a rock is not rheologically plausible (Powell \& Downes, 1990), especially if the process is 
accompanied by deformation (Brown, 1994; Sawyer et al., 1999) which is the case in the Roc de Frausa Massif. By contrast, if an initial water content $\sim 2.5 \mathrm{~mol} . \% \mathrm{H}_{2} \mathrm{O}$ is assumed in the protolith, only $3.5 \mathrm{~mol} \%$ melt would be produced, the solidus would be crossed near $790{ }^{\circ} \mathrm{C}$ and the assemblage of patch and schollen migmatites would be preserved with limited retrogression. Nevertheless, the small melt fraction produced is not consistent with the percentage of leucosome observed in patch and schollen migmatites ( $\sim 8$ and $\sim 38$ vol. $\%$, respectively). In addition, it cannot reproduce the mineral assemblage of the stromatic migmatites and residual melanosomes.

Another drawback of this model relates to the amount of water added and the composition of the migmatites. Although the mineral assemblage of residual melanosomes is reproduced from $\sim 13$ mol. $\% \mathrm{H}_{2} \mathrm{O}$ added, more water $\left(\sim 35 \mathrm{~mol} . \% \mathrm{H}_{2} \mathrm{O}\right)$ needs to be added to the rock to produce the composition of residual melanosomes. This is an unrealistic amount of water to be released from the gabbro-diorite. Conversely, mass balance calculations from the composition of the rocks (Table S2) indicate that if residual rocks were derived from the protolith, around $55 \mathrm{~mol} \%$ melt would have been lost. This constrains a maximum value of water around $12 \mathrm{~mol} . \%$.

In summary, a fluid-present melting event open to fluid infiltration but closed for melt can reproduce the mineral assemblages of the different types of migmatite if different amounts of water are added to the protolith. However, the predicted amounts of melt produced are very unlikely to be retained and the granulite facies assemblages formed will be replaced by amphibolite facies assemblages during cooling. Besides, the large amount of water that has to be added to the system to produce the composition of residual melanosomes is not consistent with the maximum value of water obtained by mass balance calculations. In order to preserve the granulite facies assemblages, the generated melt must be removed from the rock at high-temperature. Consequently, an open system for both fluid and melt is required.

\section{Fluid-present melting in a system open to fluid and melt}

This model intends to simulate a continuous process of expulsion of water from the crystallizing gabbro-diorite to the country rock, with migmatization and extraction of melt. Although such processes may be continuous we can only model them as a series of alternating melting episodes followed by melt extraction and rehydration of the protolith composition. The aims are to assess the effect of different degrees of interaction between water, melt and residue on the country rock and quantify the amount of melt produced and segregated. For this, a series of pseudosections showing the effect of melt-loss events ( $T-X_{\text {melt loss }}$ diagrams) alternating with fluid-infiltration events $\left(T-M\left(\mathrm{H}_{2} \mathrm{O}\right)\right.$ diagrams) were constructed for the hypothetical protolith at a fixed pressure of $5.5 \mathrm{kbar}$. The pseudosections were assembled in the compound diagram of Fig. 10, starting with the diagram depicted in Fig. 8. The abscissa-axis represents the $\mathrm{SiO}_{2}$ content of the protolith and the subsequent residual compositions (in $\mathrm{mol} . \% \mathrm{SiO}_{2}$ ) and the accumulated melt proportion removed from the protolith $\left(X_{\text {melt loss }}\right)$ after each melting episode. In each melt-loss event, the melt produced $(\sim 3-22 \mathrm{~mol} . \%$ melt $)$ is completely removed at peak temperature $\left(790^{\circ} \mathrm{C}\right)$ considering that the deformational environment (syn-D2) favors the redistribution (loss) of the generated melt. The residue obtained at each melt loss event represents the composition of a new rock system into which water was incorporated at each rehydration event $\left(T-M\left(\mathrm{H}_{2} \mathrm{O}\right)\right.$ diagrams). The amount of water added to the residue had to produce an amount of melt comparable to the amount of leucosome present in the samples and similar to the rheological critical melt percentage (20 $\pm 10 \mathrm{vol} . \%$; Arzi, 1978). As the composition of the protolith 
becomes more infertile, smaller batches of water are incorporated (decreasing from 4.7 to $0.8 \mathrm{~mol} . \% \mathrm{H}_{2} \mathrm{O}$ ), aiming to emulate the decrease in water released by the crystallizing gabbro-diorite. The process is performed iteratively until all the assemblages present in the migmatites are reproduced.

As in the dehydration melting model (Fig. 8), the mineral assemblage q-g-bisill-cd-ksp-liq corresponding to patch migmatites will be preserved if the first melt batch $(\sim 14 \mathrm{~mol} . \%)$ is removed from the system (green star in Figs $8 \& 10-\mathrm{R} 1)$. If residue $(\mathrm{R} 1)$ is rehydrated $\left(\mathrm{R} 1 \mathrm{H}+4.7 \mathrm{~mol} . \% \mathrm{H}_{2} \mathrm{O}\right)$, more melt will be generated $(\sim 22$ mol.\%). The resultant path will follow a horizontal line and $\mathrm{K}$-feldspar will be consumed. If the rock cools while the melt is being extracted (blue A and B arrows in Fig. 10), the new assemblage (q-g-bi-sill-cd-liq) will be variably retrogressed. Interestingly, if an accumulated melt ( $\sim 25$ mol.\% melt; blue A arrow on Fig. 10) remains segregated within the rock and crystallizes during cooling, the rock will undergo partial to complete retrogression mostly in areas of the rock adjacent to leucosomes (e.g. White \& Powell, 2002). Thus, biotite will form selvedges, prismatic sillimanite will overgrow fibrolite, garnet will be partially corroded to biotite, cordierite content will decrease and quartz-enriched leucosomes will gradually crystallize, as schollen migmatites show (Figs 4 \& S4). Nevertheless, if the melt is partially or completely removed (blue B arrow and green star at R2 in Fig. 10), the assemblage (q$\mathrm{g}-\mathrm{bi}-\mathrm{sill}-\mathrm{cd})$ will be preserved with no retrogression. This modeled assemblage coincides with that of patch and schollen migmatites with a variable amount of leucosome present in the rock (for instance, $\sim 38$ vol.\% in the calculated schollen migmatites).

Following several fluid-infiltration and melt-loss events (R2H-R3 \& R3H-R4), the mineral assemblage of schollen migmatites will be reproduced until all the melt has been segregated or lost ( $\sim 58$ mol. \% melt) and all the sillimanite consumed (around 51 mol.\% $\mathrm{SiO}_{2}$ ). Samples will retain variable amounts of melt and retrogression during cooling paths (C and D arrows in Fig. 10) or will be preserved as residues in R3 and R4 (green stars in Fig. 10).

After running out of sillimanite the assemblage $\mathrm{q}-\mathrm{g}-\mathrm{bi}-\mathrm{cd}$ corresponding to that of stromatic migmatites is preserved at R5 and R6. At R5H more than 60 mol.\% melt accumulated will have been produced and lost. If part of the melt remains in chemical contact with the residue and crystallizes during cooling (yellow arrows on Fig. 10), the rock adjacent to leucosome will present a limited range of retrogression: garnet mode will decrease while retrograde biotite, cordierite, quartz and plagioclase will be formed. At distal parts from melt segregations, the peak assemblage will be preserved and the rock will experience no retrogression. This can be the case for the stromatic migmatites, which contain 40 vol.\% leucosome and little or no retrogression of leucosomes and adjacent areas in the melanosome (Figs 2e,f \& S3).

Finally, if residue $\mathrm{R} 6$ is rehydrated $\left(\mathrm{R} 6 \mathrm{H}+1.1 \mathrm{~mol} . \% \mathrm{H}_{2} \mathrm{O}\right)$, quartz will be consumed. Removing melt at R7 will have the effect of preserving the g-bi-cd assemblage. A cooling path between R6 and R7 (red arrow on Fig. 10) implies the reincorporation of retrograde quartz, a slight increase in the mode of biotite, cordierite and plagioclase and a decrease of garnet. This retrograde assemblage corresponds to that of residual melanosomes (Fig. S5). Thus, residual melanosomes will have lost $\sim 69$ mol.\% melt. 
The evolution of the protolith during the melting-rehydration events is synthesized in Fig. 11. The amount of melt formed and removed in one event attains a maximum in the second melting event. The melt produced in the following events decreases as the rock becomes less fertile. The accumulated melt proportion migrated or extracted from the rock system is $\sim 69 \mathrm{~mol} . \%$ during the prograde to peak evolution, whereas the residue left after melt loss is $\sim 48 \mathrm{~mol} . \%$. In the residues, the loss of Kfeldspar is related to the decrease in $\mathrm{K}_{2} \mathrm{O}$ and the loss of sillimanite to the impoverishment of $\mathrm{Al}_{2} \mathrm{O}_{3}$ with respect to $\mathrm{MgO}$ and $\mathrm{FeO}$, which contributes to the modal increase in cordierite, garnet and ilmenite. As the rock becomes $\mathrm{SiO}_{2}$ unsaturated, the system runs out of quartz. This modeled evolution reproduces the mineral assemblages and modal content of the different migmatite types from patch, schollen and stromatic migmatites, and residual melanosomes. In all cases, the assemblages present in the melanosome domains correspond to situations of complete melt loss whereas situations of partial melt loss reproduce the assemblages along the borders of the leucosomes, where some retrograde phases are present in the melanosome (Fig. 10).

\section{COMPARING MODELED AND ANALYZED ROCK COMPOSITIONS}

To test the model of multiple melt-loss-fluid infiltration events, the $X_{\mathrm{Fe}}$ values of modeled residues are compared with those measured on biotite, cordierite and garnet from the migmatite samples (Table $\mathrm{S} 1$ and Figs $\mathrm{S} 1 \&$ 5). In general, the $X_{\mathrm{Fe}}$ ratio for biotite, cordierite and garnet from the modeled residues (R1-R7) is fairly constant, whereas that of real samples is more variable. Biotite from the residues has a mean $X_{\mathrm{Fe}}{ }^{\mathrm{bi}}$ $=0.56$. In contrast, that measured in the samples ranges between 0.42 and 0.65 . For cordierite, the mean $X_{\mathrm{Fe}}$ for residues is 0.41 and that for migmatite samples ranges from 0.29 to 0.48 . For garnet, the $X_{\mathrm{Fe}}$ value for residues is between 0.80 (R1) and 0.81 (R7), whereas that of garnet cores varies from 0.95 for schollen migmatites, 0.84 for patch migmatites, 0.76 for residual melanosomes and 0.72 for stromatic migmatites. The $X_{\mathrm{Fe}}$ of biotite, cordierite and garnet for modeled residues is in all cases included in the samples range. However, the wider $X_{\mathrm{Fe}}$ values of analyzed minerals may be interpreted as retrograde re-equilibration. As a result, it may be concluded that the calculated values for the residues match reasonably well those of the samples analyzed.

The whole-rock compositions of the residues obtained from modeling (Table S3) are also compared with the analyzed non-migmatitic, migmatitic and igneous rocks from the Roc de Frausa Massif (Tables S2 \& S4). Relationships between major elements are shown in the $\mathrm{SiO}_{2}-\mathrm{Al}_{2} \mathrm{O}_{3}-\left(\mathrm{FeO}+\mathrm{MgO}+\mathrm{TiO}_{2}\right)$ and $\mathrm{SiO}_{2}-\mathrm{Al}_{2} \mathrm{O}_{3}-$ $\left(\mathrm{K}_{2} \mathrm{O}+\mathrm{Na}_{2} \mathrm{O}\right)$ ternary plots (Fig. 12). The depletion of $\mathrm{SiO}_{2}$ (grey arrow in Fig. 12) of all modeled and analyzed rocks is accompanied by a linear decrease in the A/AFMT and by an increase in the $\mathrm{A} / \mathrm{AKN}$ ratios. At one end of the thick grey arrow are analyzed leucogranites and modeled anatectic melts that have similar compositions, whereas at the other end lie residual melanosome samples and the last modeled residue (R7). Vectors of mineral compositions drawn from the average protolith composition (large gray circle in Fig. 12) divide different fields: melt-rich rocks are aligned along the quartz vector together with leucogranites and modeled anatectic melts, whereas meltdepleted rocks lie in the field bounded by the cordierite and garnet vectors (Fig. 12a) or by the cordierite vector (Fig. 12b) coinciding with the enrichment in cordierite and garnet in residual melanosomes. The composition of residues (R1 to R7) matches the composition of patch and schollen migmatites and residual melanosomes. In stromatic migmatites, the major-element whole-rock composition involving high $\mathrm{SiO}_{2}, \mathrm{CaO}$ and $\mathrm{Na}_{2} \mathrm{O}$, and low $\mathrm{Al}_{2} \mathrm{O}_{3}$ appear to be inconsistent with a model of multiple melt loss accompanied by fluid-fluxed melting. However, they are largely compatible with an 
infiltrating melt (e.g. Hasalová et al., 2008b) that did not equilibrate with the residual rock or with loss of contact between melt and residue. The fact that all modeled and analyzed rocks are well correlated suggests that progressive fluid-fluxed melting and melt loss during contact metamorphism is a viable model for the genesis of this suite of migmatites.

\section{DISCUSSION AND CONCLUSIONS}

Patch, stromatic and schollen migmatites and residual melanosomes were formed in the inner contact aureole of the Ceret gabbro-diorite stock in the Roc de Frausa Massif (eastern Pyrenees) coeval with the D2 deformation event. Distinct meso- and microscale structural features, mineral assemblages and mineral and whole-rock composition reveal that the migmatites evolved from a common protolith of pelitic composition. We used petrological modeling to investigate the influence of water in open-system melting for the $P-T$ conditions recorded in the contact aureole, which enabled us to propose a petrogenetic model for the origin of the migmatites.

The sequence of mineral growth in all types of migmatite is similar despite the loss of minerals from the starting mineral assemblage (Fig. 3). Fibrolitic sillimanite and biotite grew during the onset of the D1 event (Figs 2-4). Biotite-breakdown melting in the presence of sillimanite produced garnet, K-feldspar and melt during the prograde history (syn-D1). During the decompressive history (syn-D2), both cordierite and intergrowths of cordierite with spinel coexisting with garnet resulted from a biotitebreakdown melting reaction that consumed first sillimanite and then quartz as suggested by Yardley \& Barber (1991) and White \& Powell (2011). These reactions generated a water-undersaturated melt, reaching up to $\sim 14$ mol.\% (Fig. S6) forming isolated pools as shown by the patch migmatites (Fig. 2a,b). A heterogeneous influx of fluid released by the crystallizing gabbro-diorite was incorporated during D2 causing local variations in melt productivity (up to $\sim 60 \mathrm{~mol} \% \%$; Fig. 10). The fluid influx resulted in an increase in $\mathrm{Al}_{2} \mathrm{O}_{3}$ in the melt (e.g. Acosta-Vigil et al., 2003; Weinberg \& Hasalová, 2015). In consequence, prismatic sillimanite was formed on cooling as observed in the schollen migmatites (Fig. 4c). A further impact of water influx is a decrease in $\mathrm{K}_{2} \mathrm{O}$ in the melt (e.g. Gardien et al., 2000), forming a K-feldspar poor (or absent) leucosome (e.g. Patiño Douce \& Harris, 1998). This is shown by the presence of K-feldspar only as blebs included in plagioclase in schollen migmatites or by its absence in other schollen migmatites, stromatic migmatites and residual melanosomes. Peritectic garnet, sillimanite and cordierite survived without significant retrogression because of melt loss (Powell \& Downes, 1990; Brown, 2002; White \& Powell, 2002).

The mineral and whole-rock composition of the migmatites reflect a progressive change towards more residual rocks in which patch migmatites and residual melanosomes are end-members (Figs $5 \& 6$ ). With respect to neighboring nonmigmatitic rocks of the massif (e.g. $\sim 55$ to $63 \mathrm{wt} \% \% \mathrm{SiO}_{2}$ ), patch and schollen migmatites with biotite-sillimanite-rich melanosome underwent small changes in mineral $\left(X_{\mathrm{Fe}}\right.$ ratios of biotite, cordierite and garnet) and whole-rock (e.g. $\sim 50$ to $56 \mathrm{wt} . \%$ $\mathrm{SiO}_{2}$ ) composition, whereas cordierite-garnet rich residual melanosomes (e.g. $\sim 40$ to 47 wt.\% $\mathrm{SiO}_{2}$ ) display considerable variation. The whole-rock composition of stromatic migmatites (e.g. $\sim 57$ to $63 \mathrm{wt} \% \% \mathrm{SiO}_{2}$ ) is similar to that of non-migmatites. This fact combined with a low $X_{\mathrm{Fe}}$ ratio of biotite, cordierite and garnet suggest a late infiltrating melt batch that did not interact with the melanosome, keeping the mineral assemblage and composition unchanged. 
Deformation (D2) coeval with the emplacement of the gabbro-diorite was an efficient mechanism for preferential redistribution of melt and for melt loss. In patch migmatites, a small melt fraction was formed ( $\sim 8$ vol.\% leucosome) and remained in F2 fold hinges or in granular or weakly foliated leucosomes parallel to S2. This melt is interpreted to have segregated to low-pressure sites within short distances (mm to cmscale), which is characteristic of the early stages of partial melting (McLellan, 1988; Brown et al., 1995a,b; Vigneresse et al., 1996; Slagstad et al., 2005 and references therein). The melt fraction was increased at least cumulatively up to $\sim 40 \mathrm{vol} . \%$ leucosome, which is located at dilatant sites (D2 fold hinges, shear bands or interboudin partitions) in schollen migmatites or parallel to S2 in stromatic migmatites. In residual melanosomes, complete removal of the melt resulted from syn-anatectic high strain during D2 while a restitic assemblage developed with high modal content of cordierite and garnet ( $>95$ vol.\% melanosome). Accordingly, melting and melt loss is interpreted to have taken place at two scales. Grain-scale melt segregation took place in patch migmatites whereas larger-scale melting and melt loss occurred in the other migmatite types. These two scales of melting can be related to two thresholds defined in static environments by Vigneresse et al. (1996), although in the case of these migmatites they were favored by deformation. Patch migmatites without connected melt pockets would be produced below a liquid percolation threshold occurring at the onset of melting $(\sim 8$ vol.\%). The other migmatites would form above a melt escape threshold (20-25 vol.\%), which corresponds to melt segregation and transfer over large distances towards the upper crust (Sawyer, 1994).

The $P-T$ paths recorded by the migmatites are clockwise and involved a higher pressure event at $\sim 7-8$ kbar coeval with D1, whereas D2 occurred during decompression to $5 \mathrm{kbar}$ followed by essentially isobaric cooling from $850{ }^{\circ} \mathrm{C}$ to approximately $700{ }^{\circ} \mathrm{C}$ (Figs S2 to S5). During decompression, high temperature was maintained as indicated by the presence of cordierite in the leucosome. The water released by the crystallizing gabbro-diorite led to a continuous process of fluid-fluxed melting and melt loss in an open system (Fig. 10). This process provided a mechanism that cumulatively yielded a large amount of melt (up to 60 mol.\%) most of which was expelled, thus producing the four types of migmatite (Fig. 11). On cooling from high temperature, the different amounts of melting and melt loss resulted in diverse degrees of interaction between melt and residue and melt crystallization. Granulite facies mineral assemblages were preserved at the solidus because the melt was either isolated or completely removed from the reacting system during the retrograde history, which was water-undersaturated.

In conclusion, this paper outlines a fluid infiltration-melting-melt loss process in an open system during contact metamorphism that could be locally accompanied by melt infiltration. On a larger scale, this process may be a part of the differentiation of the crust and the migration of magmas to the upper crust. Leucogranites can represent melt pathways through which the partially melted rocks were drained.

\section{ACKNOWLEDGMENTS}

This work is part of C. Aguilar PhD Thesis and has benefited from the Spanish Commission for Science and Technology, research project CGL2010-21298. The Spanish Ministerio de Ciencia e Innovación (MICINN) provided a FPI grant (BES2008-001841) to C. Aguilar. We would like to thank Dr. Juan Gómez-Barreiro and Dr. Pedro Castiñeiras for their moral support in the modal analysis of different part of migmatites. George von Knorring improved the English version of the paper. 
Comments provided by the Journal reviewers, Dr. Edward W. Sawyer and Dr. Chris Yakymchuk, and editor Dr. Michael Brown are greatly appreciated.

\section{REFERENCES}

Acosta-Vigil, A., London, D., Morgan, G. B. \& Dewers, T. A., 2003. Solubility of excess alumina in hydrous granitic melts in equilibrium with peraluminous minerals at $700-800{ }^{\circ} \mathrm{C}$ and $200 \mathrm{MPa}$, and applications of the aluminum saturation index. Contribution to Mineralogy and Petrology, 146, 100-119.

Ague, J. J., 1991. Evidence for major mass transfer and volume strain during regional metamorphism of pelites. Geology, 19, 855-858.

Aguilar, C., Liesa, M., Castiñeiras, P. \& Navidad, M., 2014. Late-Variscan metamorphic and magmatic evolution in the eastern Pyrenees revealed by $\mathrm{U}-\mathrm{Pb}$ age zircon dating. Journal of Geological Society of London, 171, 181-192.

Aguilar, C., Liesa, M., Štípská, P., Schulmann, K., Muñoz, J. A. \& Casas, J. M., 2015. $P-T-t-d$ evolution of orogenic middle crust of the Roc de Frausa Massif (Eastern Pyrenees): A result of horizontal crustal flow and Carboniferous doming? Journal of Metamorphic Geology, 33 (3), 273 - 294.

Arzi, A. A., 1978. Critical phenomena in the rheology of partially melted rocks. Tectonophysics, 44, 173-184.

Baldwin, J. A., Powell, R., Brown, M., Moraes, R. \& Fuck, R. A., 2005. Modelling of mineral equilibria in ultrahigh-temperature metamorphic rocks from the AnápolisItauçu-Complex, central Brazil. Journal of Metamorphic Geology, 23, 511-531.

Barbey, P., 1991. Restites in migmatites and authoctonous granites: their main features and their genesis. In: Didier, J. \& Barbarin, B. (eds), Enclaves and granite petrology. Elsevier. Developments in Petrology, 13, 479- 492.

Barbey, P., Brouand, M., Le Fort, P. \& Pêcher, A., 1996. Granite-migmatite genetic link: The example of the Manaslu granite and Tibetan Slab migmatites in central Nepal. Lithos, 38, 63-79.

Barbey, P., Macaudiere, J. \& Nzenti, J. P., 1990. High-pressure dehydration melting of metapelites: Evidence from the migmatites of Yaounde (Cameroon). Journal of Petrology, 31, 401-427.

Barraud, J., Gardien, V., Allemand, P. \& Grandjean, P., 2001. Analogue modelling of melt segregation and migration during deformation. Physics and Chemistry of the Earth (A), 26, 317-323.

Barraud, J., Gardien, V., Allemand, P. \& Grandjean, P., 2004. Analogue models of melt-flow networks in folding migmatites. Journal of Structural Geology, 26, 307324.

Brown, M., 1994. The generation, segregation, ascent and emplacement of granite magma: The migmatite-to-crustally-derived granite connection in thickened orogens. Earth-Science Reviews, 36, 83-130. 
Brown, M., 2002. Retrograde processes in migmatites and granulites revisited. Journal of Metamorphic Geology, 20, 25-40.

Brown, M., 2012. Introduction to a virtual issue on crustal melting. Journal of Metamorphic Geology, 30, 453-456.

Brown, M., Averkin, Y. A., McLellan, E. \& Sawyer, E. W., 1995a. Melt segregation in migmatites. Journal of Geophysical Research, 100, B8, 655-679.

Brown, M. A., Brown, M., Carlson, W. D. \& Denison, C., 1999. Topology of syntectonic melt flow networks in the deep crust: inferences from three dimensional images of leucosome geometry in migmatites. American Mineralogist, 84, 17931818 .

Brown, M., Rushmer, T. \& Sawyer, E. W., 1995b. Introduction to special section: Mechanisms and consequences of melt segregation from crustal protoliths. Journal of Geophysical Research: Solid Earth, 100, B8, 15551-15563.

Castiñeiras, P., Navidad, M., Liesa, M., Carreras, J. \& Casas, J. M., 2008. U-Pb zircon ages (SHRIMP) for Cadomian and Early Ordovician magmatism in the Eastern Pyrenees: new insights into the pre-Variscan evolution of the northern Gondwana margin. Tectonophysics, 461, 228-239.

Coggon, R. \& Holland, T. J. B., 2002. Mixing properties of phengitic micas and revised garnet-phengite thermobarometers. Journal of Metamorphic Geology, 20, 683-696.

Droop, G. T. R. \& Brodie, K. H., 2012. Anatectic melt volumes in the thermal aureole of the Etive Complex, Scotland: The roles of fluid-present and fluid-absent melting. Journal of Metamorphic Geology, 30, 843-864.

Druguet, E. \& Carreras, J., 2006. Analogue modelling of syntectonic leucosomes in migmatitic schists. Journal of Structural Geology, 28, 1734-1747.

Fyfe, W. S., 1973. The granulite facies, partial melting and the Archean crust. Royal Society of London Philosphical Transactions, Series A, 273, 457-461.

Fyfe, W. S., Price, N. J. \& Thompson, A. B., 1978. Fluids in the Earth's Crust. Elsevier, Amsterdam, pp. 383.

Gardien, V., Thompson, A. B. \& Ulmer, P., 2000. Melting of biotite + plagioclase + quartz gneisses; the role of $\mathrm{H}_{2} \mathrm{O}$ in the stability of amphibolite. Journal of Petrology, 41, 651-666.

Guernina, S. \& Sawyer, E. W., 2003. Large-scale melt-depletion in granulite terranes: An example from the Archean Ashuanipi Subprovince of Quebec. Journal of Metamorphic Geology, 21, 181-201.

Hasalová, P., Schulmann, K., Lexa, O., Štípská, P., Hrouda, P., Ulrich, S., Haloda, J. \& Tycová, P., 2008a. Origin of migmatites by deformation-enhanced melt infiltration of orthogneiss: a new model based on quantitative microstructural analysis. Journal of Metamorphic Geology, 26, 29-53. 
Hasalová, P. Štípská, P., Powell, R., Schulmann, K., Janousek, V. \& Lexa, O., 2008 b. Transforming mylonitic metagranite by open-system interactions during melt flow. Journal of Metamorphic Geology, 26, 55-80.

Holland, T. J. B., \& Powell, R., 1998. An internally consistent thermodynamic data set for phases of petrological interest. Journal of Metamorphic Geology, 16, 309-343.

Holland, T. J. B \& Powell, R., 2003. Activity-composition relations for phases in petrological calculations: an asymmetric multicomponent formulation. Contributions to Mineralogy and Petrology, 145, 492-501.

Johnson, T. E., Brown, M. \& Solar, G. S., 2003. Low-pressure subsolidus and suprasolidus phase equilibria in the MnNCKFMASH system: Constraints on conditions of regional metamorphism in western Maine, northern Appalachians. American Mineralogist, 88, 624-638.

Kriegsman, L. M. \& Hensen, B. J., 1998. Back reaction between restite and melt: Implications for geothermobarometry and pressure-temperature paths. Geology, 26, 1111-1114.

Korhonen, F. J., Saito, S., Brown, M. \& Siddoway, C. S., 2010. Modeling multiple melt loss events in the evolution of an active continental margin. Lithos, 116, 230-248.

Liesa, M. \& Carreras, J., 1989. On the structure and metamorphism of the Roc de Frausa Massif (Eastern Pyrenees). Geodinamica Acta, 3, 149-161.

Mackenzie, D. P., 1984. The generation and compaction of partially molten rocks. Journal of Petrology, 25, 713-765.

Marchildon, N. \& Brown, M., 2001. Melt segregation in late syn-tectonic anatectic migmatites: An example from the Onawa contact aureole, Maine, U.S.A. Physics and Chemistry of the Earth (A), 26, 225-229.

Maurel, O., 2003. L'exhumation de la Zone axiale des Pyrénées orientales: Une approche thermo-chronologique multi-méthodes du rôle des failles. Ph.D. Thesis, Université Montpellier II, Montpellier, France, pp. 219.

McLellan, E. L., 1988. Migmatite structures in the Central Gneiss Complex, Boca De Quadra, Alaska. Journal of Metamorphic Geology, 6, 517-542.

Milord, I., Sawyer, E. W. \& Brown, M., 2001. Formation of diatexite migmatite and granite magma during anatexis of semi-pelitic metasedimentary rocks: An example from St. Malo, France. Journal of Petrology, 42, 487-505.

Olsen, S. N., 1982. Open and closed systems migmatites in the Front Range, Colorado. American Journal of Science, 282, 1596-1622.

Olsen, S. N., 1984. Mass-balance and mass-transfer in migmatites from the Colorado Front Range. Contributions to Mineralogy and Petrology, 85, 30-44.

Patiño Douce, A. E., \& Harris, N., 1998. Experimental constraints on Himalayan anatexis. Journal of Petrology, 39, 689-710. 
Pattison, D. R. M. \& Harte, B., 1988. Evolution of structurally contrasting anatectic migmatites in the 3-kbar Ballachulish aureole, Scotland. Journal of Metamorphic Geology, 6, 475-494.

Powell, R., 1983a. Processes in granulite-facies metamorphsim. In: Atherton, M. P. \& Gribble, C. D. (eds), Migmatites, melting and metamorphism. Shiva, Nantwich, pp. 127-139.

Powell, R., 1983b. Fluids and melting under upper amphibolite facies conditions. Journal of the Geological Society, London, 140, 629-633.

Powell, R. \& Downes, J., 1990. Garnet Porphyroblast-bearing leucosomes in metapelites: mechanisms and an example from Brocken Hill, Australia. In: Ashworth, J. R. \& Brown, M. (eds), High Temperature Metamorphism and Crustal Anatexis. Unwin-Hyman, London, pp. 105-123.

Powell, R., Holland, T. J. B. \& Worley, B., 1998. Calculating phase diagrams involving solid solutions via non-linear equations, with examples using THERMOCALC. Journal of Metamorphic Geology, 16, 577-588.

Rutter, E. H., 1997. The influence of deformation on the extraction of crustal melts: A consideration of the role of melt-assisted granular flow. In: Holmes, M. (ed.), Deformation-enhanced fluid transport in the Earth's crust and mantle. Chapman and Hall, London, U.K., pp. 82-110.

Sawyer, E. W., 1987. The role of partial melting and fractional crystallization in determining discordant migmatite leucosome compositions. Journal of Petrology, 28, 445-473.

Sawyer, E. W., 1991. Disequilibrium melting and the rate of melt residuum separation during migmatization of mafic rocks from the Grenville Front, Quebec. Journal of Petrology, 32, 701-738.

Sawyer, E. W., 1994. Melt segregation in the continental crust. Geology, 22, 10191022.

Sawyer, E. W., 1998. Formation and evolution of granite magmas during crustal reworking: the significance of diatexites. Journal of Petrology, 39, 1147-1167.

Sawyer, E. W., 2001. Melt segregation in the continental crust: distribution and movement of melt in anatectic rocks. Journal of Metamorphic Geology, 19, 291309.

Sawyer, E. W., 2008. Atlas of migmatites. The Canadian Mineralogist, Special Publication 9 NRC Research Press Otawa, ON. pp. 371.

Sawyer, E. W., Dombrowski, C. \& Collins, W. J., 1999. Movement of melt during synchronous regional deformation and granulite-facies anatexis, an example from the Wuluma Hills, central Australia. In: Castro, A., Fernández, C. \& Vigneresse, J. L. (eds), Understanding Granites; Integrating New and Classical Techniques. Geological Society Special Publication, 168, 221-237. 
Slagstad, T., Jamieson, R. A. \& Culshaw, N. G., 2005. Formation, crystallization, and migration of melt in the mid-orogenic crust: Muskoka domain migmatites, Grenville Province, Ontario. Journal of Petrology, 46, 893-919.

Simakin, A. G. \& Petford, N., 2003. Melt redistribution during the bending of a porous, partially melted layer. Geophysical Research Letters, 30 (11), pp. 1564.

Spear, F. S., Kohn, M. J. \& Cheney, J. T., 1999. $P-T$ paths from anatectic pelites. Contributions to Mineralogy and Petrology, 134, 17-32.

Sylvester, P. J., 1998. Post-collisional strongly peraluminous granites. Lithos, 45, 29 44.

Taylor, S. R. \& McLennan, S. M., 1985. The Continental Crust: Its Composition and Evolution. Blackwell Scientific Publications, Oxford, pp. 312.

Vanderhaeghe, O., 1999. Pervasive melt migration from migmatites to leucogranite: control of regional deformation. Tectonophysics, 312 (1), 35-55.

Vigneresse, J. L., Barbey, P. \& Cuney, M., 1996. Rheological transitions during partial melting and crystallization with application to felsic magma segregation and transfer. Journal of Petrology, 37, 1579-1600.

Vigneresse, J. L. \& Burg, J. P., 2000. Continous vs. discontinous melt segregation in migmatites: insights from a cellular automaton model. Terra Nova, 12, 188-192.

Waters, D. J., 2001. The significance of prograde and retrograde quartz-bearing intergrowth microstructures in partially melted granulite-facies rocks. Lithos, 56, 97110 .

Weinberg, R. F. \& Hasalová, P., 2015. Water-fluxed melting of the continental crust: A review. Lithos, 212-215, 158-188.

White, R. W. \& Powell, R., 2002. Melt loss and the preservation of granulite facies mineral assemblages. Journal of Metamorphic Geology, 20, 621-632.

White, R. W. \& Powell, R., 2011. On the interpretation of retrograde textures in granulite facies rocks. Journal of Metamorphic Geology, 29, 131-149.

White, R. W., Powell, R. \& Clarke, G. L., 2002. The interpretation of reaction textures in Fe-rich metapelitic granulites of the Musgrave Block, central Australia: constraints from mineral equilibria calculations in the system $\mathrm{K}_{2} \mathrm{O}-\mathrm{FeO}-\mathrm{MgO}-$ $\mathrm{Al}_{2} \mathrm{O}_{3}-\mathrm{SiO}_{2}-\mathrm{H}_{2} \mathrm{O}-\mathrm{TiO}_{2}-\mathrm{Fe}_{2} \mathrm{O}_{3}$. Journal of Metamorphic Geology, 20, 41-55.

White, R. W., Powell, R. \& Holland, T. J. B., 2001. Calculation of partial melting equilibria in the system $\mathrm{Na}_{2} \mathrm{O}-\mathrm{CaO}-\mathrm{K}_{2} \mathrm{O}-\mathrm{FeO}-\mathrm{MgO}-\mathrm{Al}_{2} \mathrm{O}_{3}-\mathrm{SiO}_{2}-\mathrm{H}_{2} \mathrm{O}$ (NCKFMASH). Journal of Metamorphic Geology, 19, 139-153.

White, R. W., Powell, R. \& Holland T. J. B., 2007. Progress relating to calculation of partial melting equilibria for metapelites. Journal of Metamorphic Geology, 25, 511527. 
White, R. W., Powell, R., Holland, T. J. B. \& Worley, B., 2000. The effect of $\mathrm{TiO}_{2}$ and $\mathrm{Fe}_{2} \mathrm{O}_{3}$ on metapelitic assemblages at greenschist and amphibolite facies conditions: mineral equilibria calculations in the system $\mathrm{K}_{2} \mathrm{O}-\mathrm{FeO}-\mathrm{MgO}-\mathrm{Al}_{2} \mathrm{O}_{3}-\mathrm{SiO}_{2}-\mathrm{H}_{2} \mathrm{O}-$ $\mathrm{TiO}_{2}-\mathrm{Fe}_{2} \mathrm{O}_{3}$. Journal of Metamorphic Geology, 18, 497-511.

Wickham, S. M., 1987. The segregation and emplacement of granitic magmas. Journal of the Geological Society of London, 144, 281-297.

Yakymchuk, C. \& Brown, M., 2014. Consequences of open-system melting in tectonics. Journal of the Geological Society, London, 171, 21-40.

Yardley, B. W. D. \& Barber, J. P., 1991. Melting reactions in the Connemara schists the role of water infiltration in the formation of amphibolite facies migmatites. American Mineralogist, 76, 848-856.

\section{SUPPORTING INFORMATION}

Additional Supporting Information may be found in the online version of this article at the publisher's web site:

Figure S1. Chemical zoning profile of garnet from four characteristic migmatitic rocks at the Ceret gabbro-diorite contact aureole.

Figure S2. $P-T$ pseudosection for patch migmatite.

Figure S3. $P-T$ pseudosection for stromatic migmatite.

Figure S4. $P-T$ pseudosection for schollen migmatite.

Figure S5. $P-T$ pseudosection for residual melanosome.

Figure S6. $P-T$ pseudosection for an average protolith.

Table S1. Representative analyses of garnet, biotite and cordierite.

Table S2. Representative whole-rock chemical compositions of the different types of migmatite and non-migmatitic rocks from the Roc de Frausa Massif.

Table S3. Residue and anatectic melt bulk compositions calculated at $5.5 \mathrm{kbar}$.

Table S4. Representative whole-rock compositions of the Ceret gabbro-diorite stock and a leucogranite from the Sant Llorenç-La Jonquera pluton.

\section{FIGURE CAPTIONS}

Fig. 1. (a) Geological map of the central and eastern part of Axial Pyrenean Zone and North Pyrenean Zone (the study area is outlined). (b) Geological sketch map of the Roc de Frausa Massif, synthetic stratigraphic column including the intrusive sheet of Sant Llorenc-La Jonquera pluton and cross-section showing the main structural relationships between the different rock units. The location of the four characteristic migmatites used in this study and the position of the structural profiles are indicated. Modified from Liesa \& Carreras (1989).

Fig. 2. Macro- to microstructural relationships in patch (a-d) and stromatic (e-f) migmatites: (a) coarse-grained lenses of leucosome embedded in a sillimanite and biotite-rich melanosome. Leucosome mostly crystallizes on S1 or in S2 axial planes; (b) biotite and sillimanite parallel to S1 foliation folded by the D2 event and patches of Kfeldspar-rich leucosome parallel to the axial plane of an F2 fold; (c) garnet including sillimanite and biotite near the rim parallel to $\mathrm{S} 1$ foliation; (d) cordierite poikiloblasts including folded S1 foliation and S2 oriented biotite; (e) alternating fine-grained melanosome layers with coarse-grained leucosomes parallel to the S2 foliation; and (f) layer of leucosome (quartz-plagioclase-garnet) hosted by cordierite-biotite-rich layers. Garnet grows parallel to the foliation in the limit of the leucosome-melanosome and spinel is included in cordierite. 
Fig. 3. Sketch of the deformation events registered in the four types of migmatite affected by contact metamorphism around the Ceret gabbro-diorite.

Fig. 4. Macro- to microstructural relationships in schollen migmatites $(a-d)$ and residuum melanosomes $(\mathrm{c}-\mathrm{f})$ : $(\mathrm{a}, \mathrm{b})$ biotite and sillimanite-rich melanosome embedded in a coarse-grained leucosome. S1 foliation defined by sillimanite and biotite-rich melanosome is folded by the D2 event; (c) prismatic sillimanite in the leucosome with inclusions trails of biotite, ilmenite and locally, green spinel parallel to S1 fabric; (d) cordierite corona around garnet porphyroblast in the leucosome; (e) massive residual melanosome with granoblastic texture; and (f) garnet porphyroblasts, biotite, ilmenite and brown spinel embedded in a cordierite-rich matrix.

Fig. 5. (a) Biotite-cordierite $X_{\mathrm{Fe}}$ composition relationships and (b) $\mathrm{Al}_{2} \mathrm{O}_{3}-\mathrm{FeO}-\mathrm{MgO}$ compositional diagram for the different migmatite types affected by the Ceret contact aureole and for non-migmatitic rocks from the Upper and Intermediate series unaffected by the contact aureole. Mineral compositions (color symbols; mol.\%) and whole-rock analyses (black symbols; mol.\%) plot at progressively lower $X_{\mathrm{Fe}}$ values for the different types.

Fig. 6. Harker plots showing the correlation between $\mathrm{SiO}_{2}$ and other major elements for the different types of migmatite formed at Ceret gabbro-diorite contact aureole, for nonmigmatitic rocks of the Roc de Frausa Massif and for the average protolith (in wt.\%). See text for explanation.

Fig. 7. $P-T$ diagram showing the different paths of migmatite. The solidus for the different samples is underlined by a dashed line.

Fig. 8. $T-X_{\text {melt }}$ pseudosection calculated at $5.5 \mathrm{kbar}$ for a range of compositions representing mixtures of residue $(X=0)$ and melt $(X=1)$ obtained from the composition of a protolith with $14 \mathrm{~mol} \% \%$ melt at $790{ }^{\circ} \mathrm{C}$ (Fig. S6). The grey circle represents the composition of the protolith. The stippled field indicates the partial preservation of granulite facies assemblage corresponding to that of patch and schollen migmatites. The molar proportion of liquid is contoured by red dashed lines and the solidus is underlined by a thick red dashed line.

Fig. 9. $T-M\left(\mathrm{H}_{2} \mathrm{O}\right)$ pseudosection calculated at $5.5 \mathrm{kbar}$ for a hypothetical protolith and contoured for the molar proportion of liquid (red dashed lines). $M\left(\mathrm{H}_{2} \mathrm{O}\right)$ is the molar content of water in mol.\%. The stippled field indicates the partial preservation of granulite facies assemblages. The solidus is underlined by a thick red dashed line. Fig. 10. Calculated $T-X_{\text {melt loss }}$ pseudosection at $5.5 \mathrm{kbar}$ showing the effect of multiple partial fluid infiltration-melt-loss events. $X_{\text {melt loss }}$ is the proportion of melt removed from the protolith composition at $790{ }^{\circ} \mathrm{C}$ in mol.\%. Stippled fields indicate the partial preservation of granulite facies assemblages. The solidus is underlined by a thick red dashed line.

Fig. 11. Sketch illustrating the seven episodes of melt-loss alternating with seven fluidinfiltration events at $5.5 \mathrm{kbar}$ and $790{ }^{\circ} \mathrm{C}$ and diagrams showing the residue/melt accumulated and the mineral proportions for the different melting episodes calculated by THERMOCALC.

Fig. 12. $\mathrm{SiO}_{2}-\mathrm{Al}_{2} \mathrm{O}_{3}-\left(\mathrm{FeO}+\mathrm{MgO}+\mathrm{TiO}_{2}\right)$ and $\mathrm{SiO}_{2}-\mathrm{Al}_{2} \mathrm{O}_{3}-\left(\mathrm{K}_{2} \mathrm{O}+\mathrm{Na}_{2} \mathrm{O}\right)$ ternary plots in mol.\% representing the composition of the hypothetical protolith and the nonmigmatitic rocks, together with the different types of migmatites produced by Ceret gabbro-diorite contact aureole (Table S2), the composition calculated by THERMOCALC for residues (R1-R7) obtained from melt-loss-rehydration modeling and for the anatectic melt at the solidus at $5.5 \mathrm{kbar}$ for the four migmatitic types (Table S3) and the representative igneous rocks from the Ceret gabbro-diorite stock and a leucogranite from the Sant Llorenç-La Jonquera pluton (Table S4). Mineral vectors 


\section{Page 26 of 49}

correspond to the mean composition of the analyzed quartz, garnet, cordierite and plagioclase. 

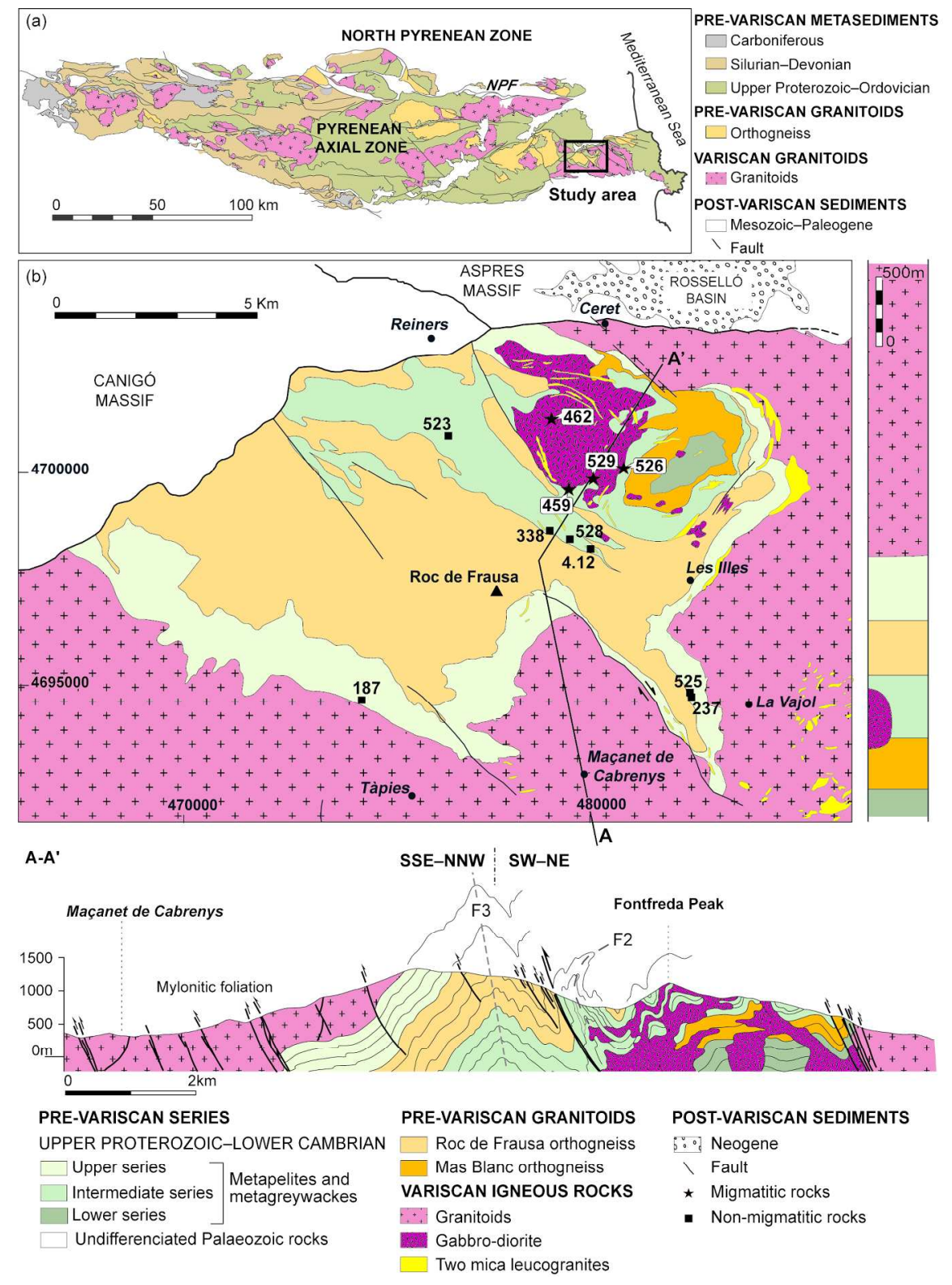

Figure 1

$175 \times 233 \mathrm{~mm}(300 \times 300$ DPI $)$ 

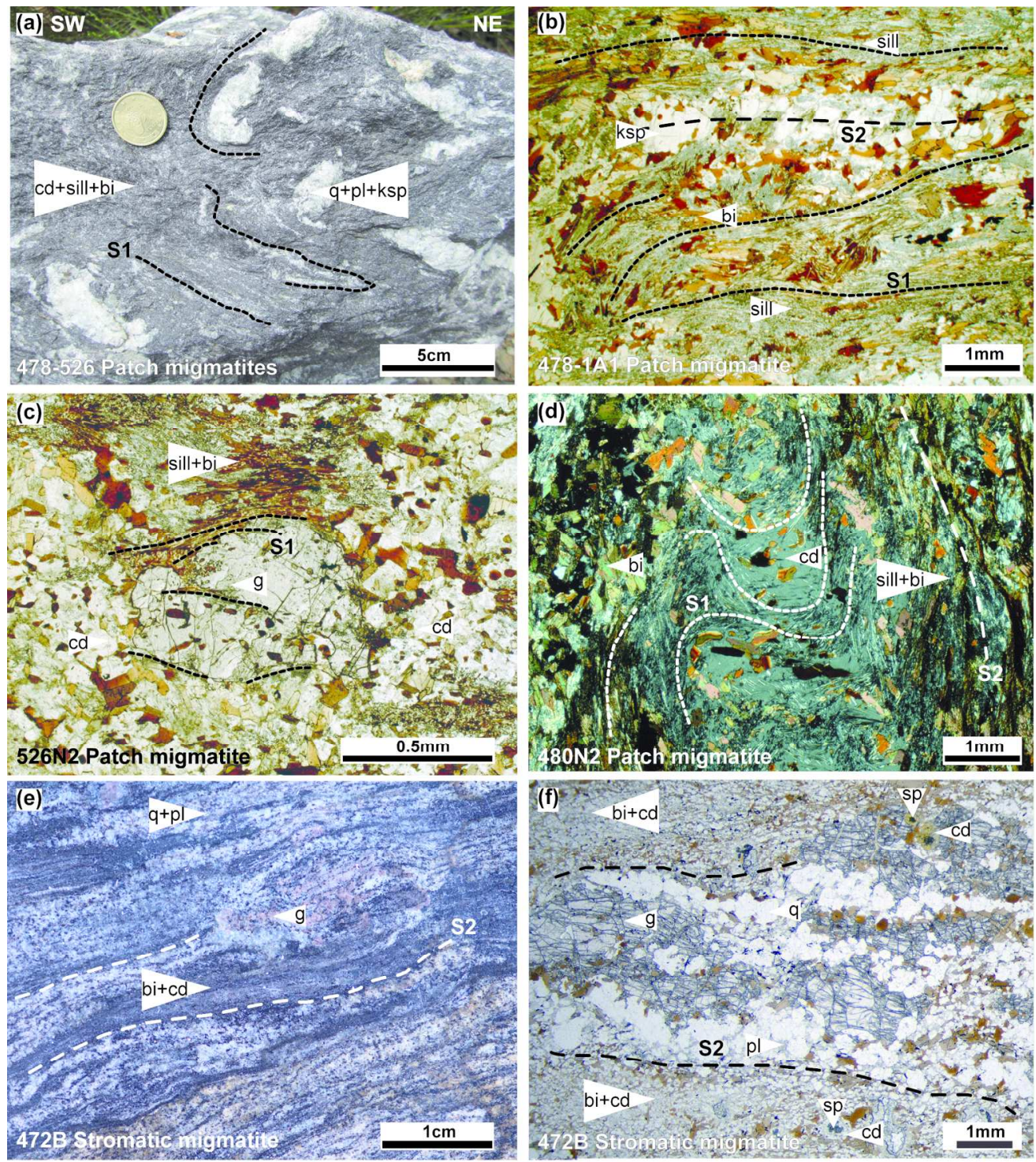

Figure 2

$169 \times 191 \mathrm{~mm}(300 \times 300$ DPI $)$ 


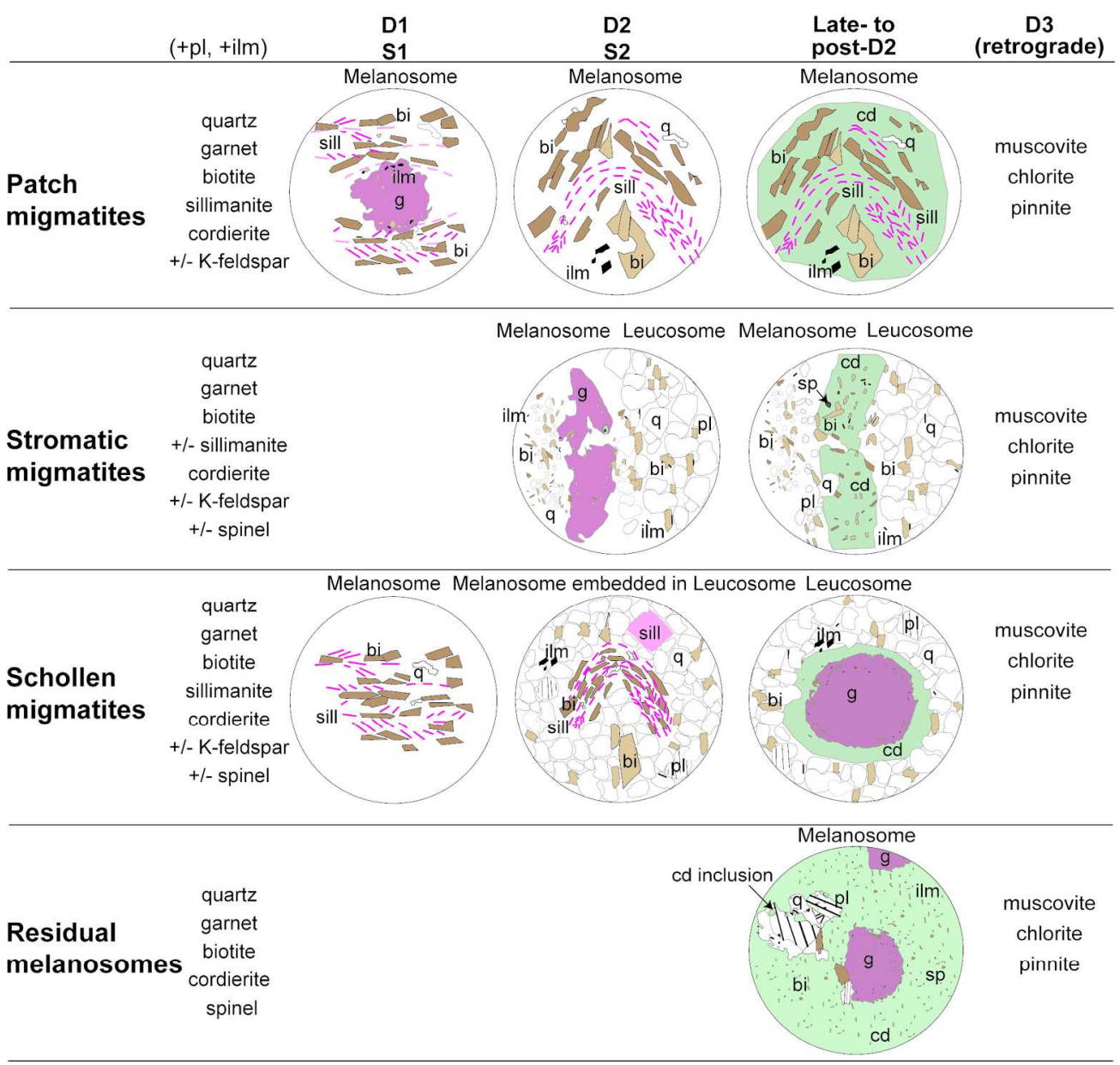

Figure 3

$177 \times 169 \mathrm{~mm}(300 \times 300$ DPI $)$ 

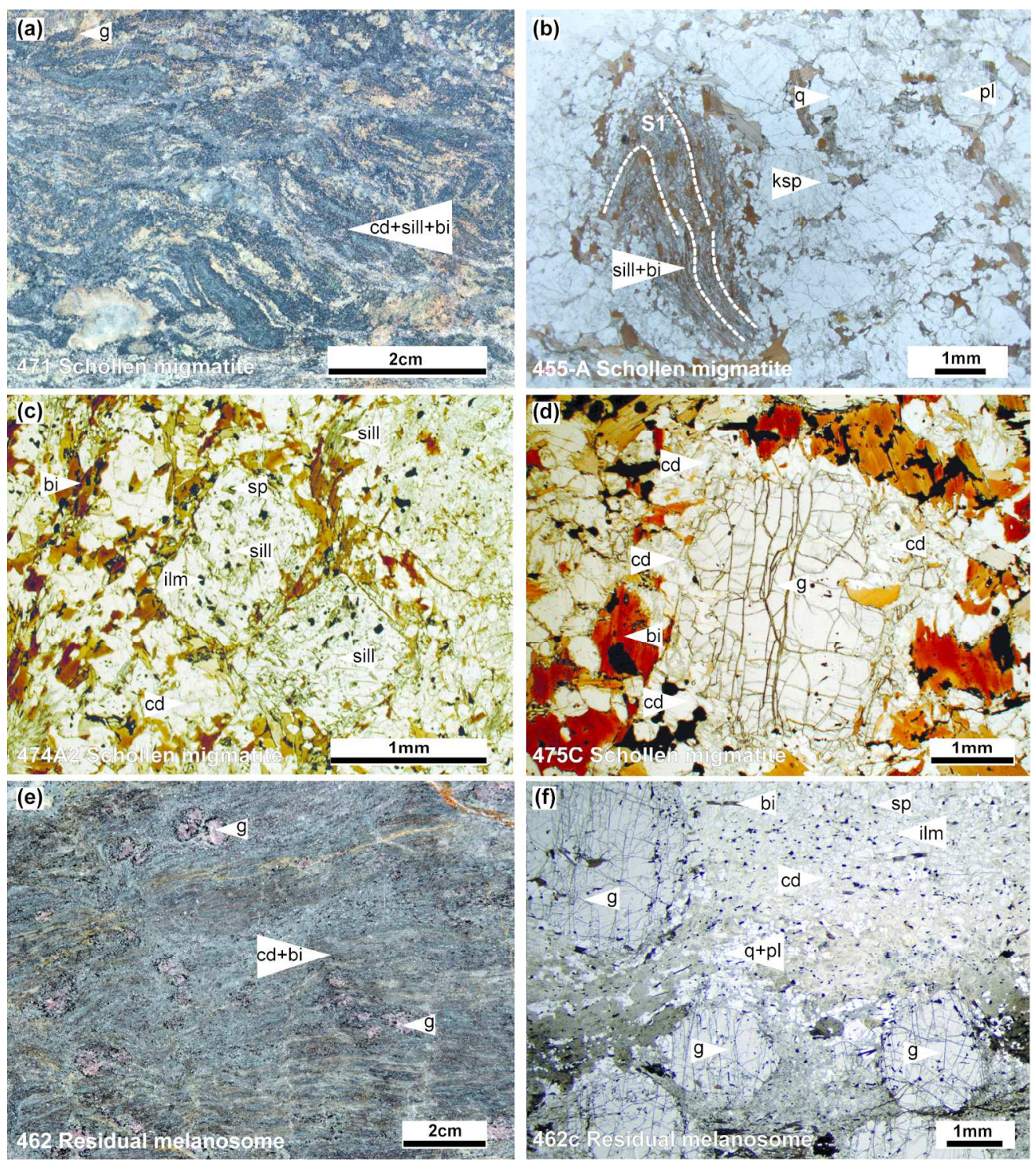

Figure 4

$168 \times 190 \mathrm{~mm}$ (300 x 300 DPI) 
(a)

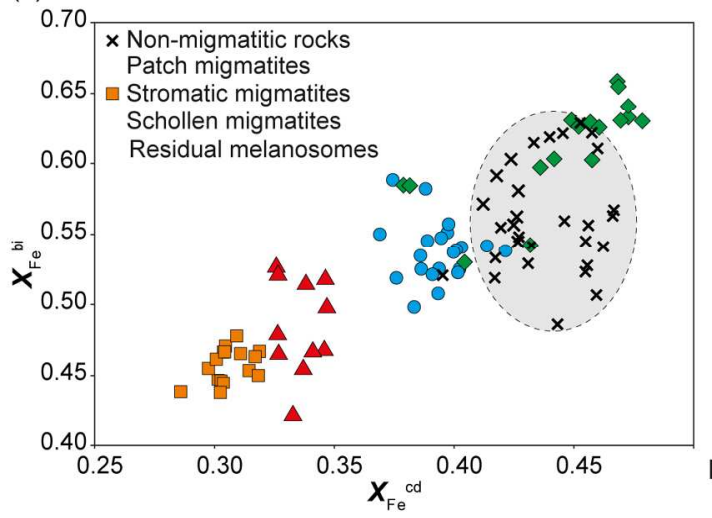

(b)

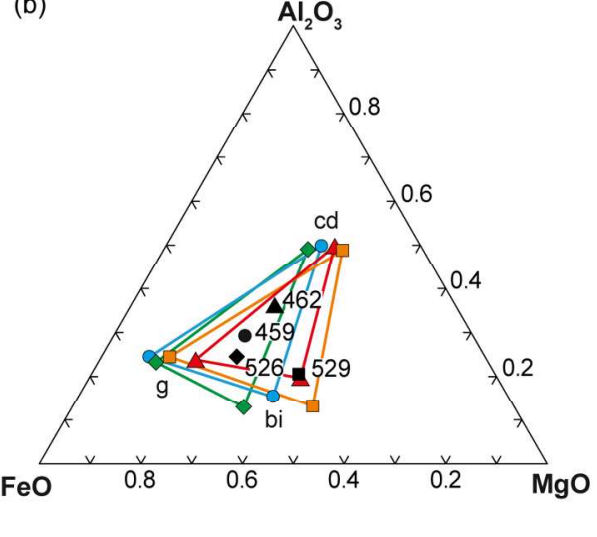

Figure 5

$171 \times 72 \mathrm{~mm}(300 \times 300$ DPI $)$ 

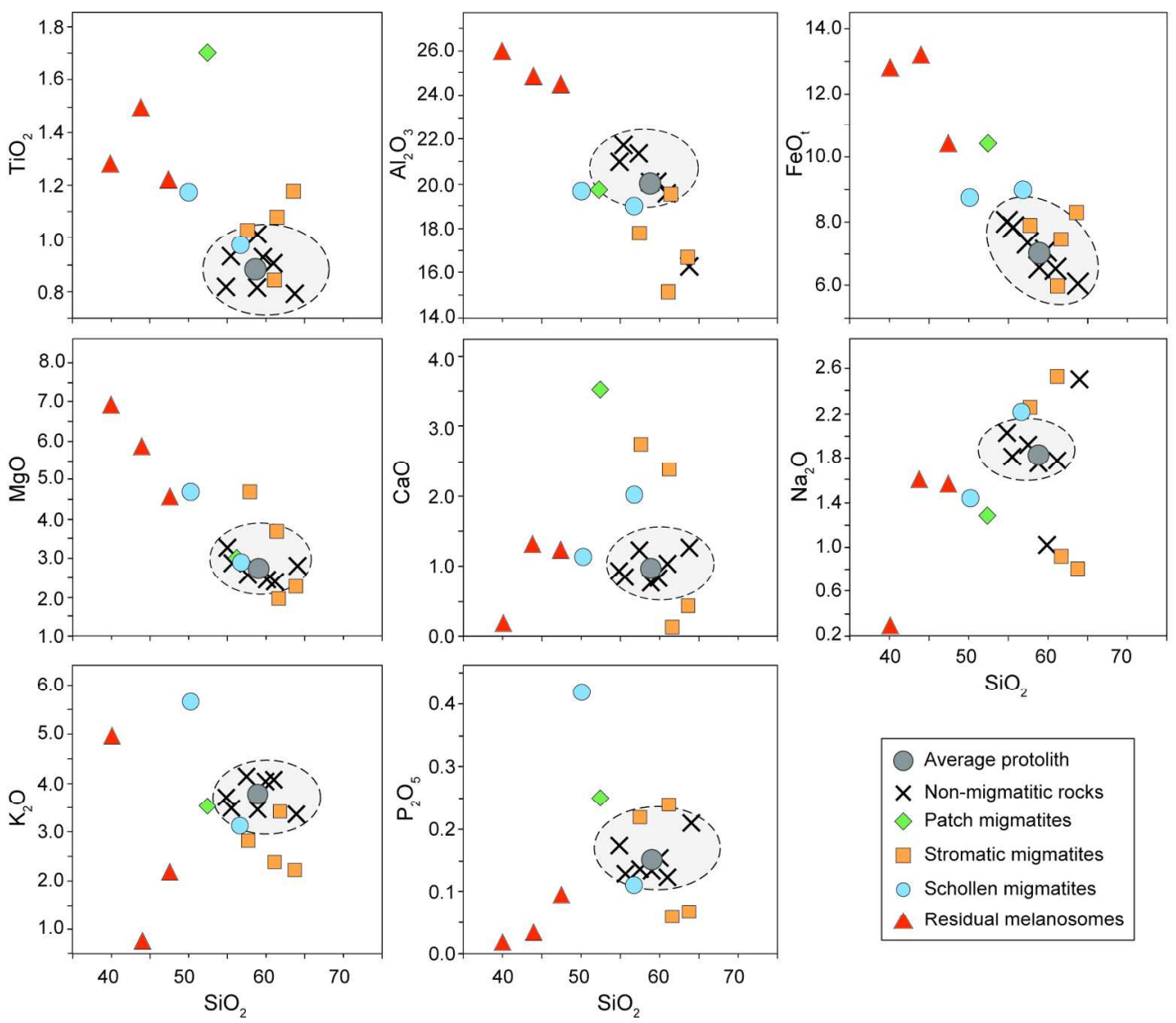

Figure 6

$171 \times 148 \mathrm{~mm}(300 \times 300 \mathrm{DPI})$ 


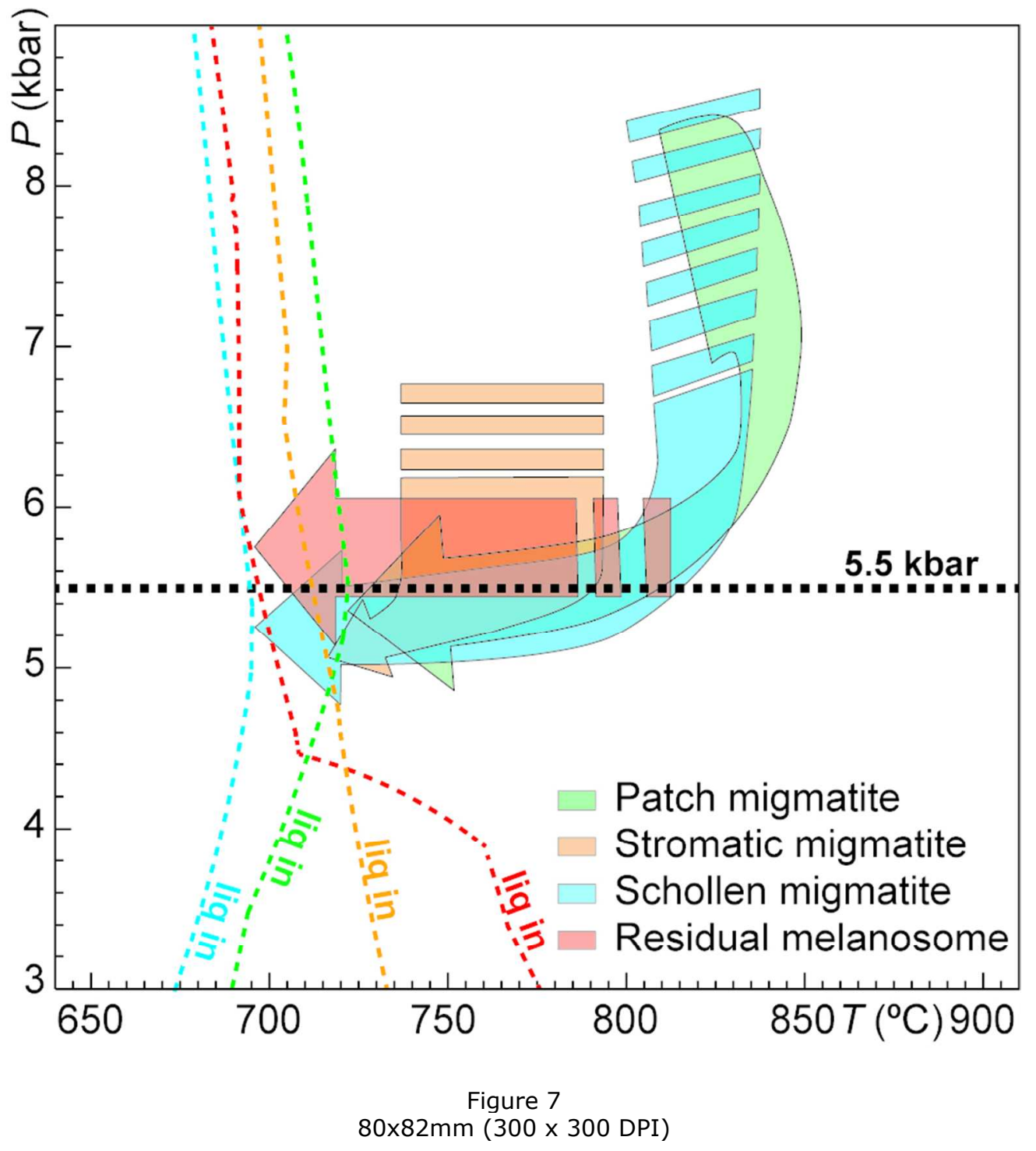




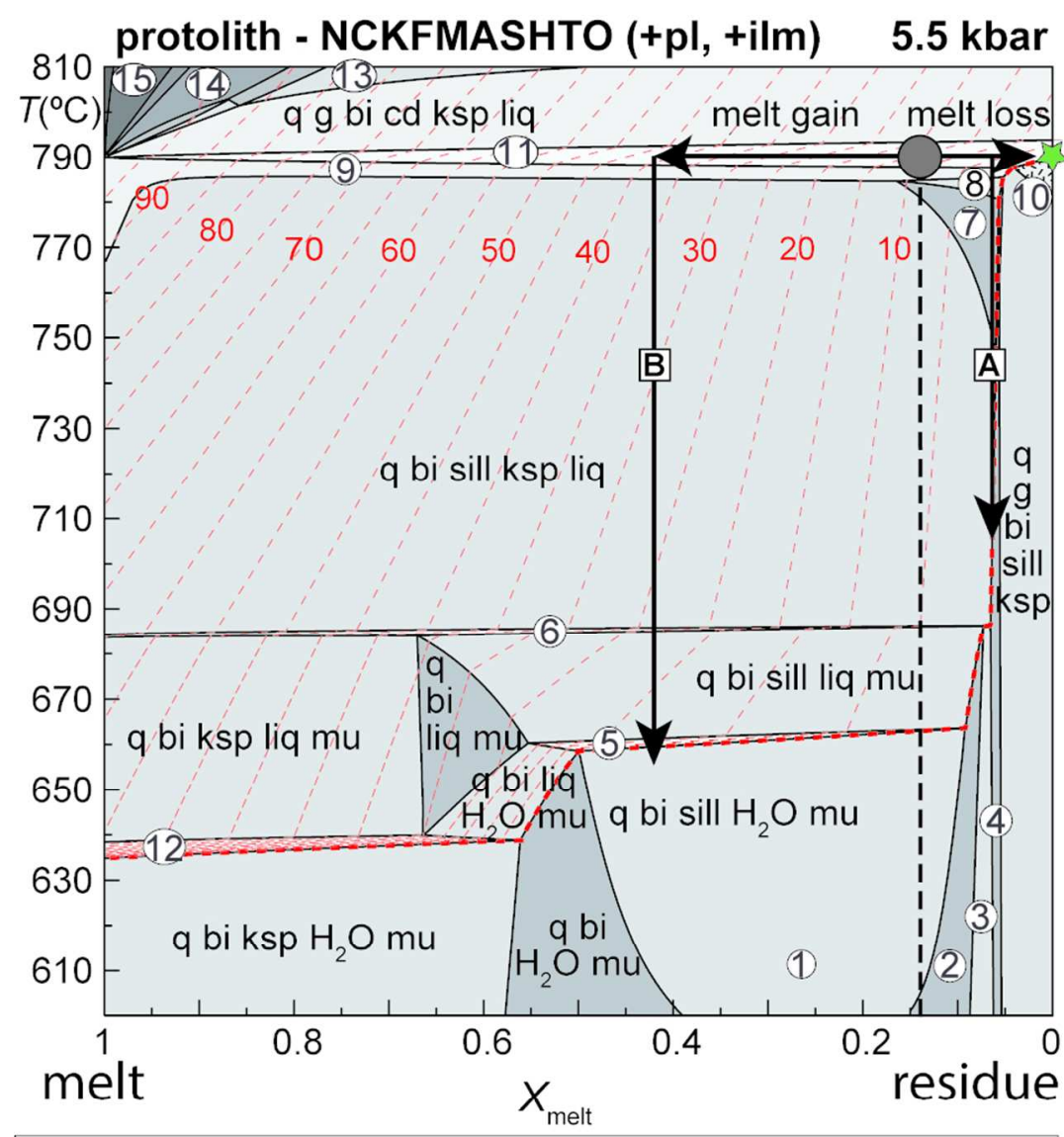

$\begin{array}{lllllllllll}\mathrm{H}_{2} \mathrm{O} & \mathrm{SiO}_{2} & \mathrm{Al}_{2} \mathrm{O}_{3} & \mathrm{CaO} & \mathrm{MgO} & \mathrm{FeO} & \mathrm{K}_{2} \mathrm{O} & \mathrm{Na}_{2} \mathrm{O} & \mathrm{TiO}_{2} & \mathrm{O}\end{array}$ $\begin{array}{lllllllllll}16.71 & 67.59 & 8.09 & 0.37 & 0.16 & 0.67 & 3.25 & 3.11 & 0.04 & 0.01 & X=1\end{array}$

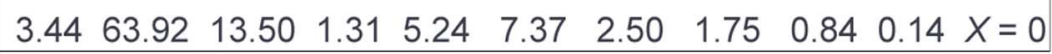

(1) $q$ bi sill $\mathrm{H}_{2} \mathrm{O}$ mu (6) $q$ bi sill ksp liq mu (11) $q \mathrm{~g}$ bi sill $\mathrm{cd}$ ksp liq (2) $q$ bi sill $m u$ (7) $q$ bi sill liq (12) $q$ bi ksp $\mathrm{H}_{2} \mathrm{O}$ liq mu

(3) q bi sill ksp mu

(4) $q$ bi sill ksp

(8) $q \mathrm{~g}$ bi sill liq (13) bi cd ksp liq

(5) $q$ bi sill liq mu (9) $\mathrm{q} g$ bi sill ksp liq (14) $\mathrm{g}$ cd liq (10) q g bi sill cd ksp (15) g cd liq (-pl)

Figure 8

$81 \times 118 \mathrm{~mm}(300 \times 300$ DPI $)$ 


\section{Page 35 of 49}

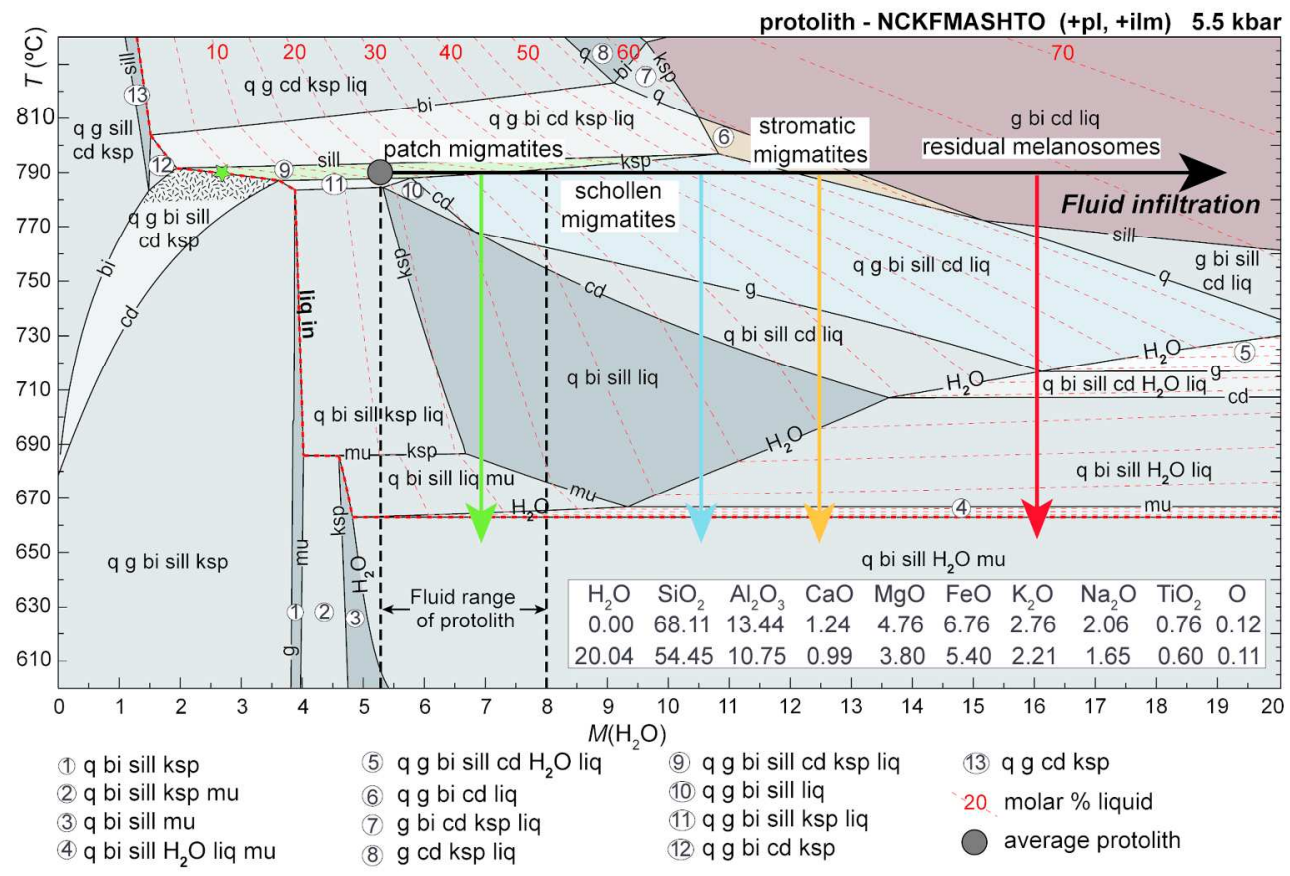

Figure 9

$173 \times 119 \mathrm{~mm}(300 \times 300$ DPI $)$ 


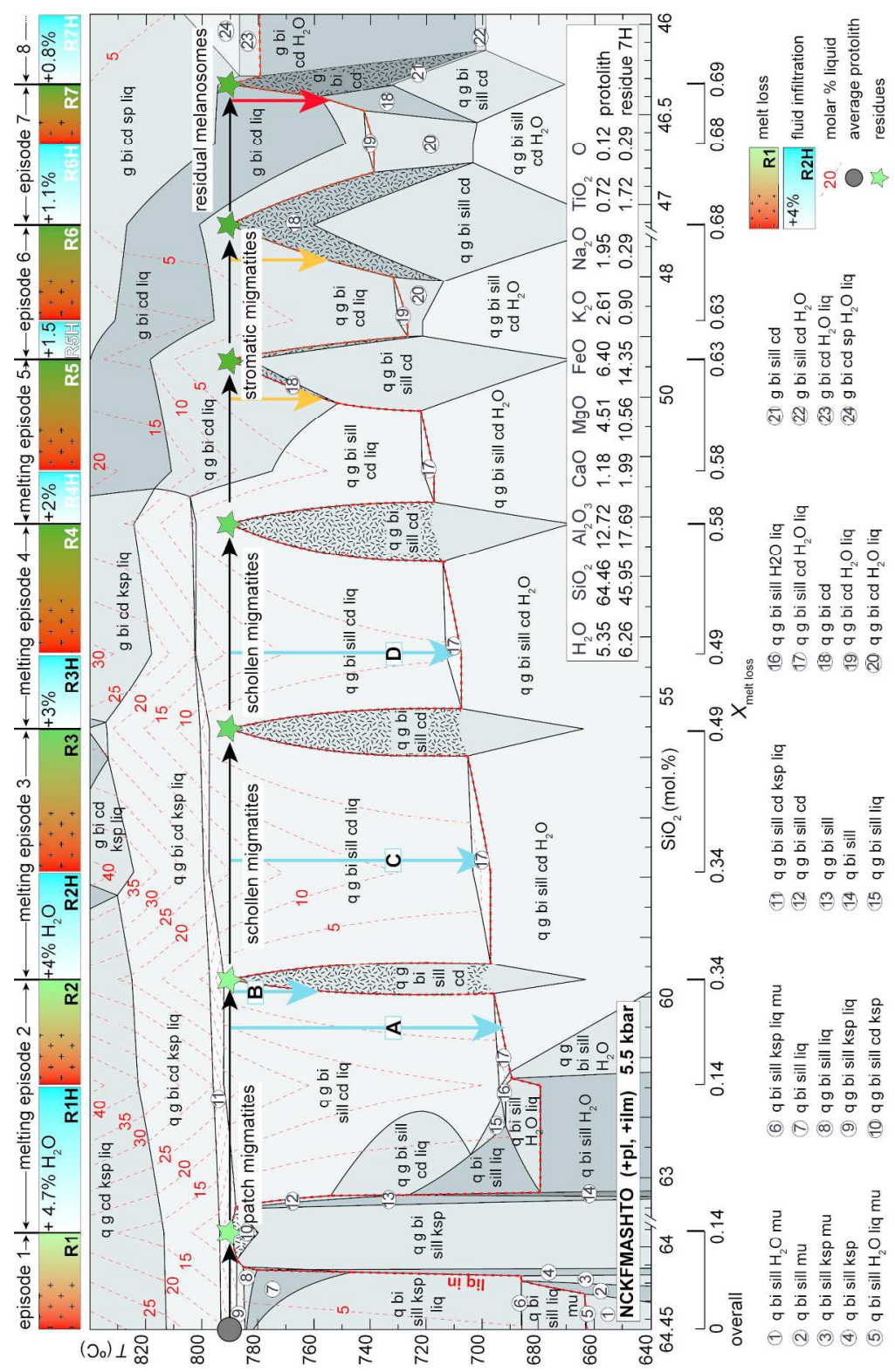

Figure 10

$158 \times 235 \mathrm{~mm}(300 \times 300 \mathrm{DPI})$ 


\section{Page 37 of 49}

14
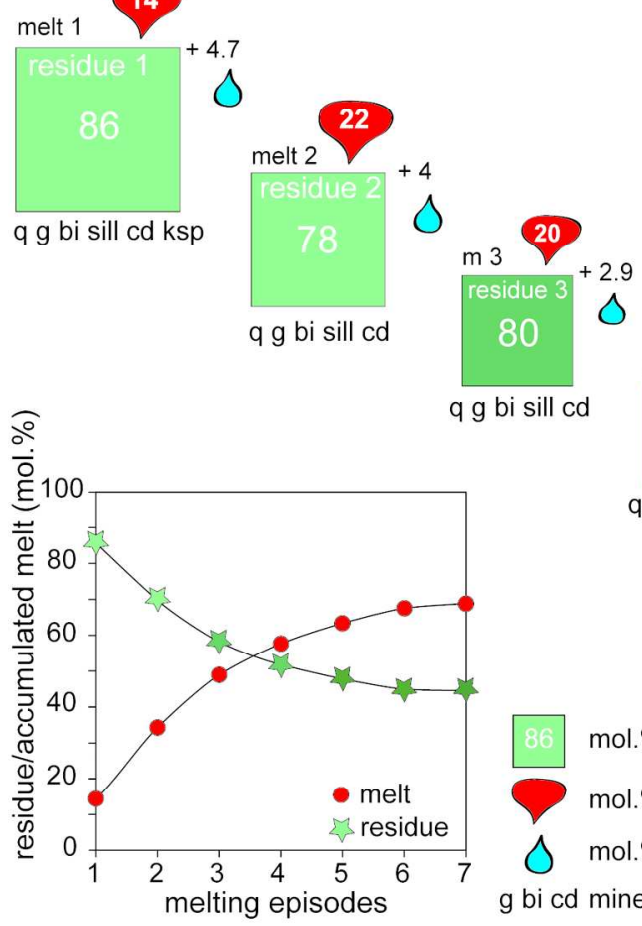

q g bi sill cd
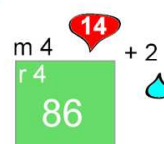

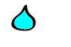

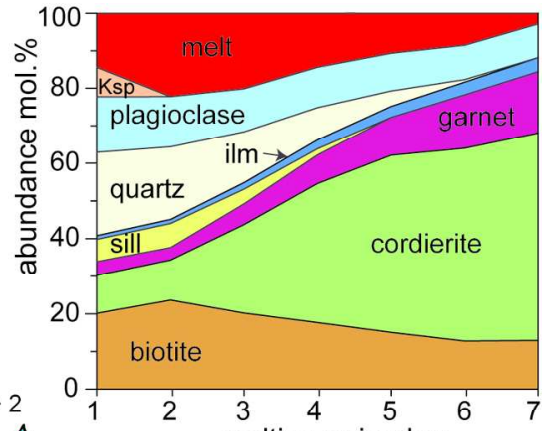

m $5{ }^{11}$ melting episodes
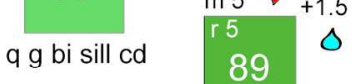

89
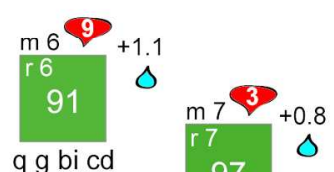

$\mathrm{q} \mathrm{g}$ bi cd

97

$\mathrm{g}$ bi cd

86 mol.\% residue from an individual melting episode

mol.\% melt in an individual melting episode

$\checkmark$ mol. $\% \mathrm{H}_{2} \mathrm{O}$ added to residue

$\mathrm{g}$ bi cd mineral assemblages in equilibrium with the melt $(+\mathrm{pl},+\mathrm{ilm})$

Figure 11

$169 \times 123 \mathrm{~mm}(300 \times 300$ DPI $)$ 


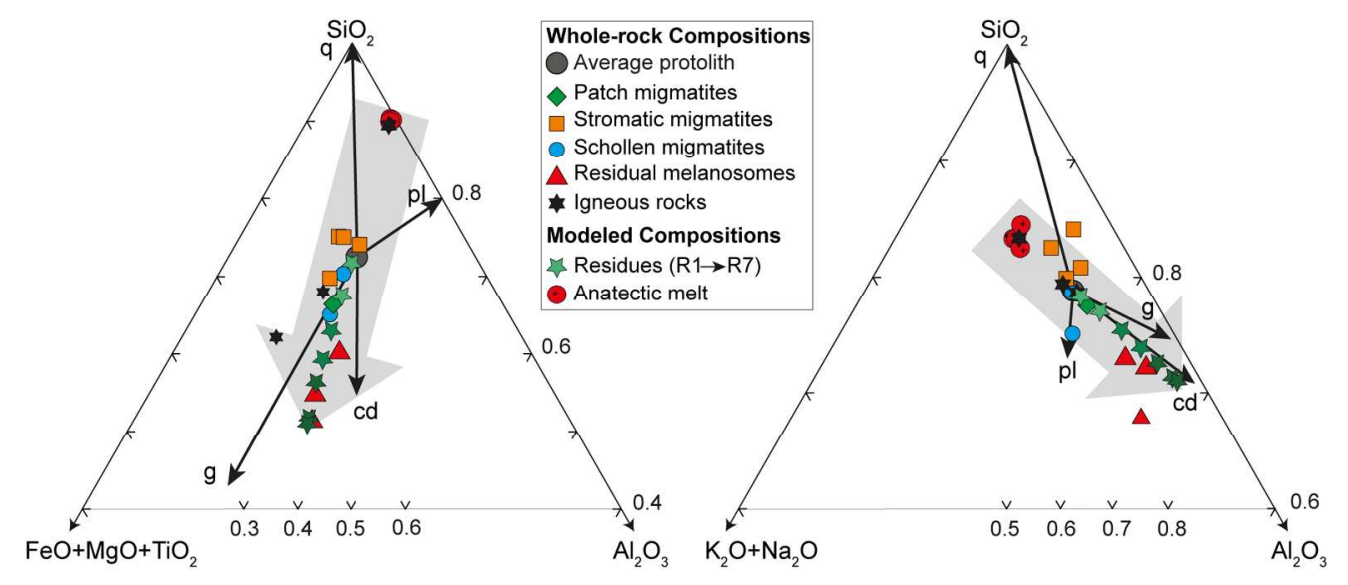

Figure 12

$172 \times 73 \mathrm{~mm}(300 \times 300 \mathrm{DPI})$ 


\section{SUPPORTING INFORMATION}

\section{Fluid-fluxed melting and melt loss in a syntectonic contact metamorphic aureole from the Variscan eastern Pyrenees}

\section{C.AGUILAR, M. LIESA, J. RECHE \& R. POWELL}

Figure S1. Chemical zoning profile of garnet from four characteristic migmatitic rocks at the Ceret gabbro-diorite contact aureole.

Figure S2. $P-T$ pseudosection (a) calculated in NCKFMASHTO using THERMOCALC for a patch migmatite (sample 526) with isopleths of molar proportions and mineral compositions for the area of interest $(\mathrm{b}-\mathrm{e})$. The solidus is underlined by a thick-dashed line.

Figure S3. $P-T$ pseudosection (a) calculated in NCKFMASHTO using THERMOCALC for a stromatic migmatite (sample 529) with isopleths of molar proportions and mineral compositions for the areas of interest $(\mathrm{b}-\mathrm{e})$. The solidus is underlined by a thick-dashed line.

Figure S4. $P-T$ pseudosection (a) calculated in NCKFMASHTO using THERMOCALC for a schollen migmatite (sample 459) with isopleths of molar proportions and mineral compositions for the areas of interest $(\mathrm{b}-\mathrm{e})$. The solidus is underlined by a thick-dashed line.

Figure S5. $P-T$ pseudosection (a) calculated in NCKFMASHTO using THERMOCALC for a residual melanosome (sample 462) with isopleths of molar proportions and mineral compositions for the areas of interest $(\mathrm{b}-\mathrm{e})$. The solidus is underlined by a thick-dashed line.

Figure S6. $P-T$ pseudosection calculated in NCKFMASHTO using THERMOCALC for an average protolith with $5.35 \mathrm{~mol} \% \% \mathrm{H}_{2} \mathrm{O}$ heating isobarically from $640{ }^{\circ} \mathrm{C}$ (subsolidus) to $790{ }^{\circ} \mathrm{C}$ (suprasolidus). Filled gray circle marks the protolith composition with $14 \mathrm{~mol} . \%$ melt used to construct the melting event diagram (Fig. 8). The molar proportion of liquid is contoured by red dashed lines and the solidus is underlined by a thick red dashed line.

Table S1. Representative analyses of garnet, biotite and cordierite for the different types of migmatite from the Intermediate series produced by the Ceret gabbro-diorite contact aureole.

Table S2. Representative whole-rock chemical analyses (in wt.\%) of the different types of migmatite and non-migmatitic rocks from the Roc de Frausa Massif. Molar fractions: A/CNK:

$\mathrm{Al}_{2} \mathrm{O}_{3} /\left(\mathrm{CaO}+\mathrm{Na}_{2} \mathrm{O}+\mathrm{K}_{2} \mathrm{O}\right) ; \mathrm{A} / \mathrm{AFMT}: \mathrm{Al}_{2} \mathrm{O}_{3} /\left(\mathrm{Al}_{2} \mathrm{O}_{3}+\mathrm{FeO}+\mathrm{MgO}+\mathrm{TiO}_{2}\right) ; \mathrm{A} / \mathrm{AKN}$ :

$\mathrm{Al}_{2} \mathrm{O}_{3} /\left(\mathrm{Al}_{2} \mathrm{O}_{3}+\mathrm{K}_{2} \mathrm{O}+\mathrm{Na}_{2} \mathrm{O}\right) ; X_{\mathrm{Si}}: \mathrm{SiO}_{2} /\left(\mathrm{SiO}_{2}+\mathrm{Al}_{2} \mathrm{O}_{3}+\mathrm{FeO}+\mathrm{MgO}+\mathrm{TiO}_{2}\right) ; X_{\mathrm{Fe}}: \mathrm{FeO} /(\mathrm{FeO}+\mathrm{MgO})$.

Average protolith: hypothetical composition of the protolith of migmatites.

Table S3. Residue and anatectic melt bulk compositions calculated at $5.5 \mathrm{kbar}$. The residue compositions are calculated for the seven melting episodes (R1-R7). Anatectic melt compositions correspond to those of the solidus for a patch migmatite (sample 526; Fig. S2), a stromatic migmatite (sample 529; Fig. S3), a schollen migmatite (sample 459; Fig. S4) and a residual melanosome (sample 462; Fig. S5).

Table S4. Representative whole-rock compositions of the Ceret gabbro-diorite stock and a leucogranite from the Sant Llorenç-La Jonquera pluton. 

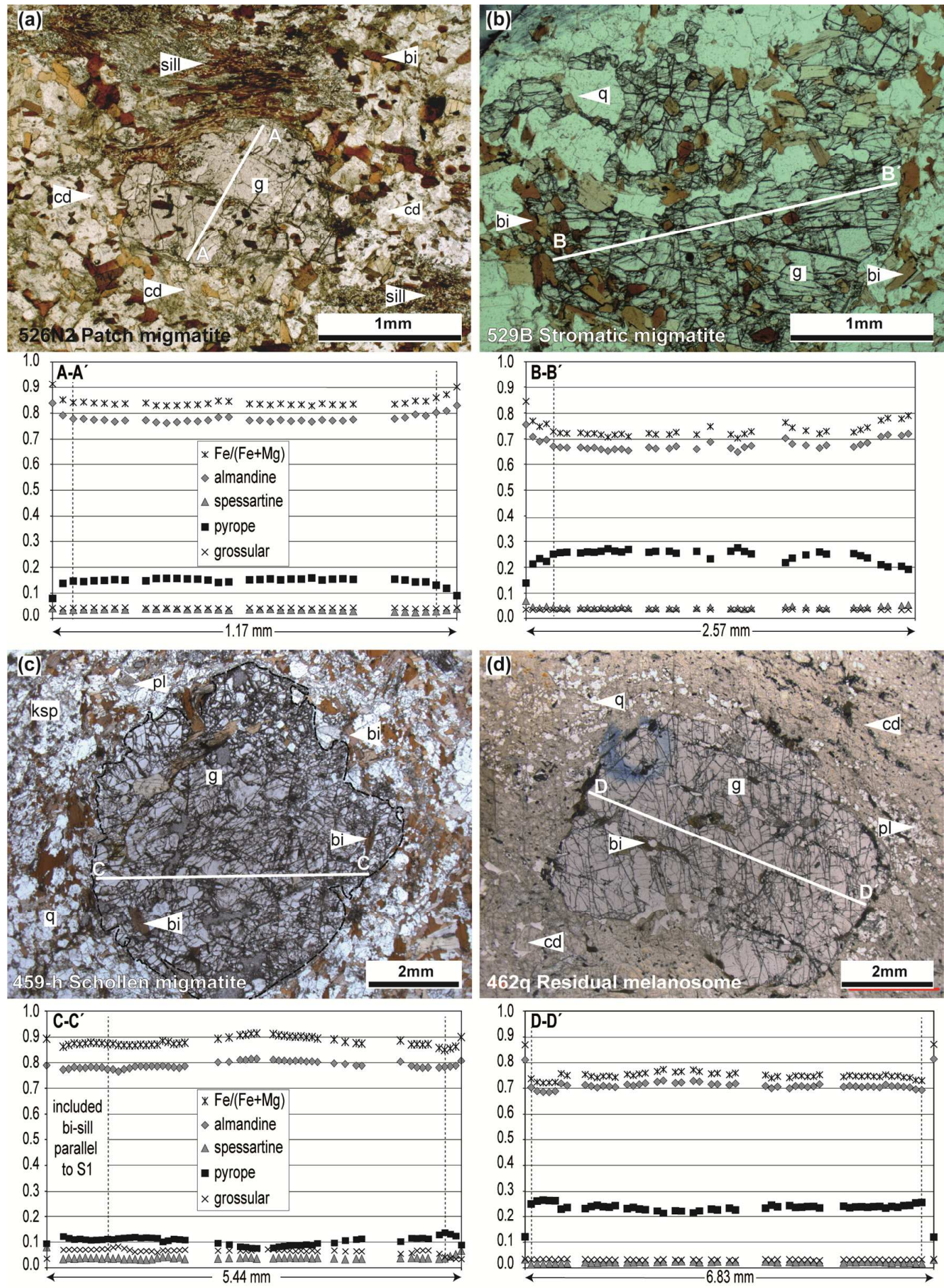

Figure S1. Chemical zoning profile of garnet from four characteristic migmatitic rocks at the Ceret gabbro-diorite contact aureole. 
(a) Patch migmatite (sample 526)
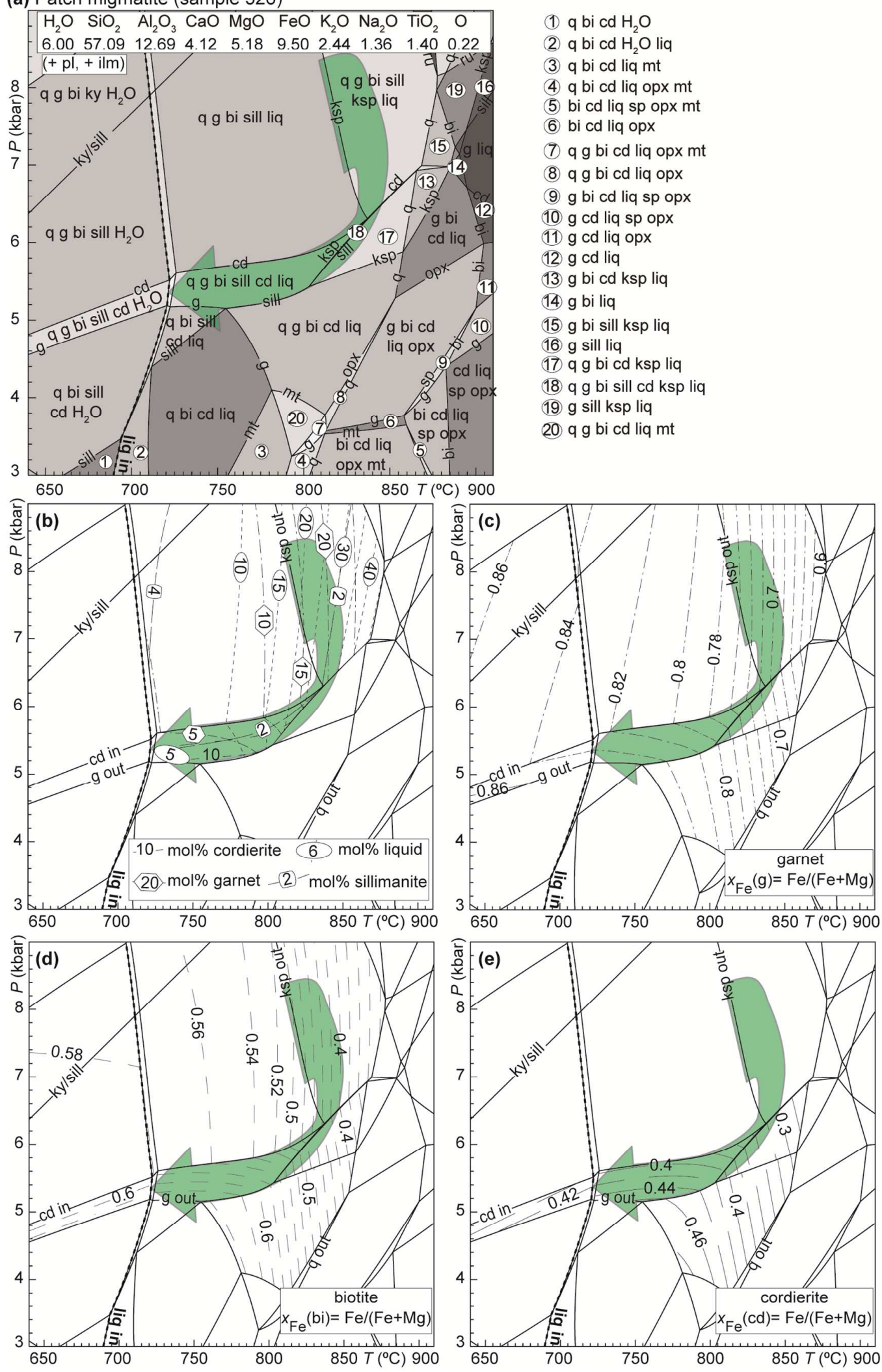

Figure S2. $P-T$ pseudosection (a) calculated in NCKFMASHTO using THERMOCALC for a patch migmatite (sample 526) with isopleths of molar proportions and mineral compositions for the area of interest $(\mathrm{b}-\mathrm{e})$. The solidus is underlined by a thick-dashed line. 
(a) Stromatic migmatite (sample 529)

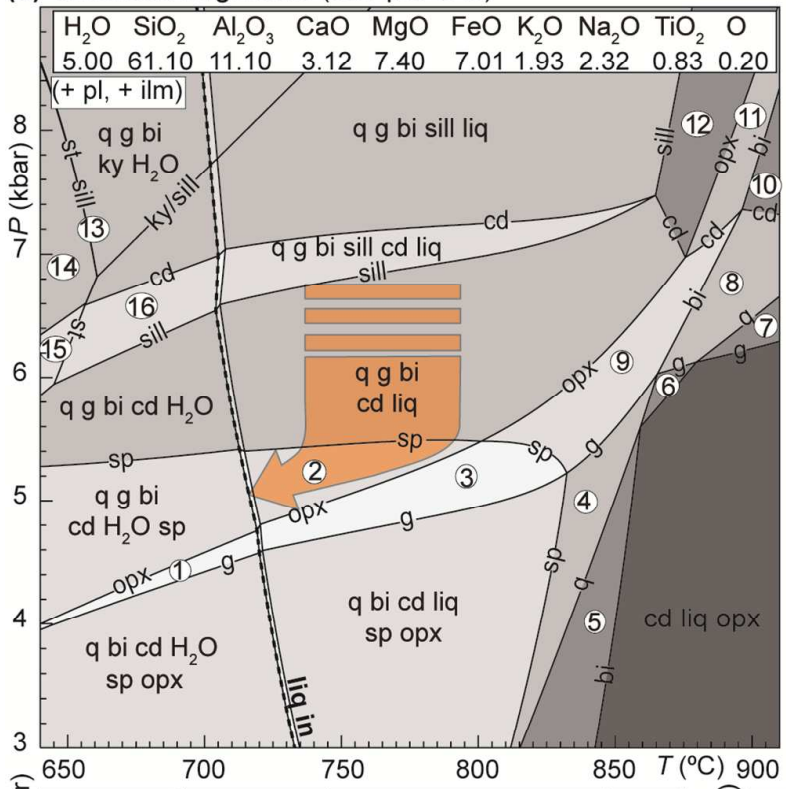

(1) $q \mathrm{~g}$ bi $\mathrm{cd} \mathrm{H}_{2} \mathrm{O}$ sp opx

(2) $q \mathrm{~g}$ bi cd liq $\mathrm{sp}$

(3) $q \mathrm{~g}$ bi cd liq $\mathrm{sp}$ opx

(4) $q$ bi cd liq opx

(5) bi cd liq opx

(6) q cd liq opx

(7) $\mathrm{g}$ cd liq opx

(8) q g cd liq opx

(9) $q \mathrm{~g}$ bi cd liq opx

(10) $q \mathrm{~g}$ liq opx

(11) $\mathrm{q} g$ bi liq opx

(12) $\mathrm{q} g$ bi liq

(13) $\mathrm{q} \mathrm{g} \mathrm{bi} \mathrm{ky} \mathrm{H}_{2} \mathrm{O}$ st

(14) $\mathrm{q} \mathrm{g} \mathrm{bi} \mathrm{H}_{2} \mathrm{O}$ st

(15) q g bi cd $\mathrm{H}_{2} \mathrm{O}$ st

(16) q g bi cd sill $\mathrm{H}_{2} \mathrm{O}$
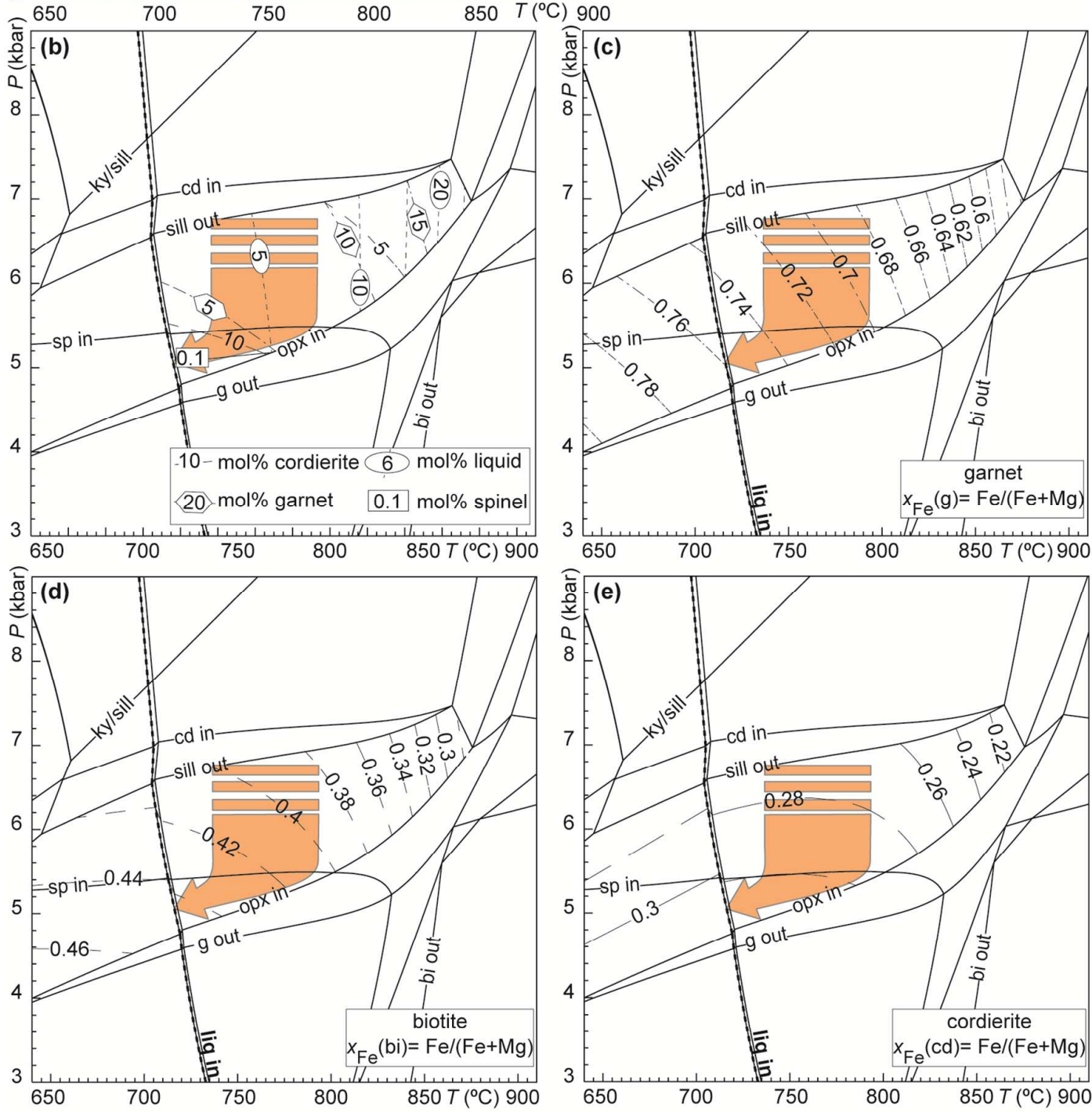

Figure S3. $P-T$ pseudosection (a) calculated in NCKFMASHTO using THERMOCALC for a stromatic migmatite (sample 529) with isopleths of molar proportions and mineral compositions for the areas of interest $(b-e)$. The solidus is underlined by a thick-dashed line. 
(a) Schollen migmatite (sample 459)
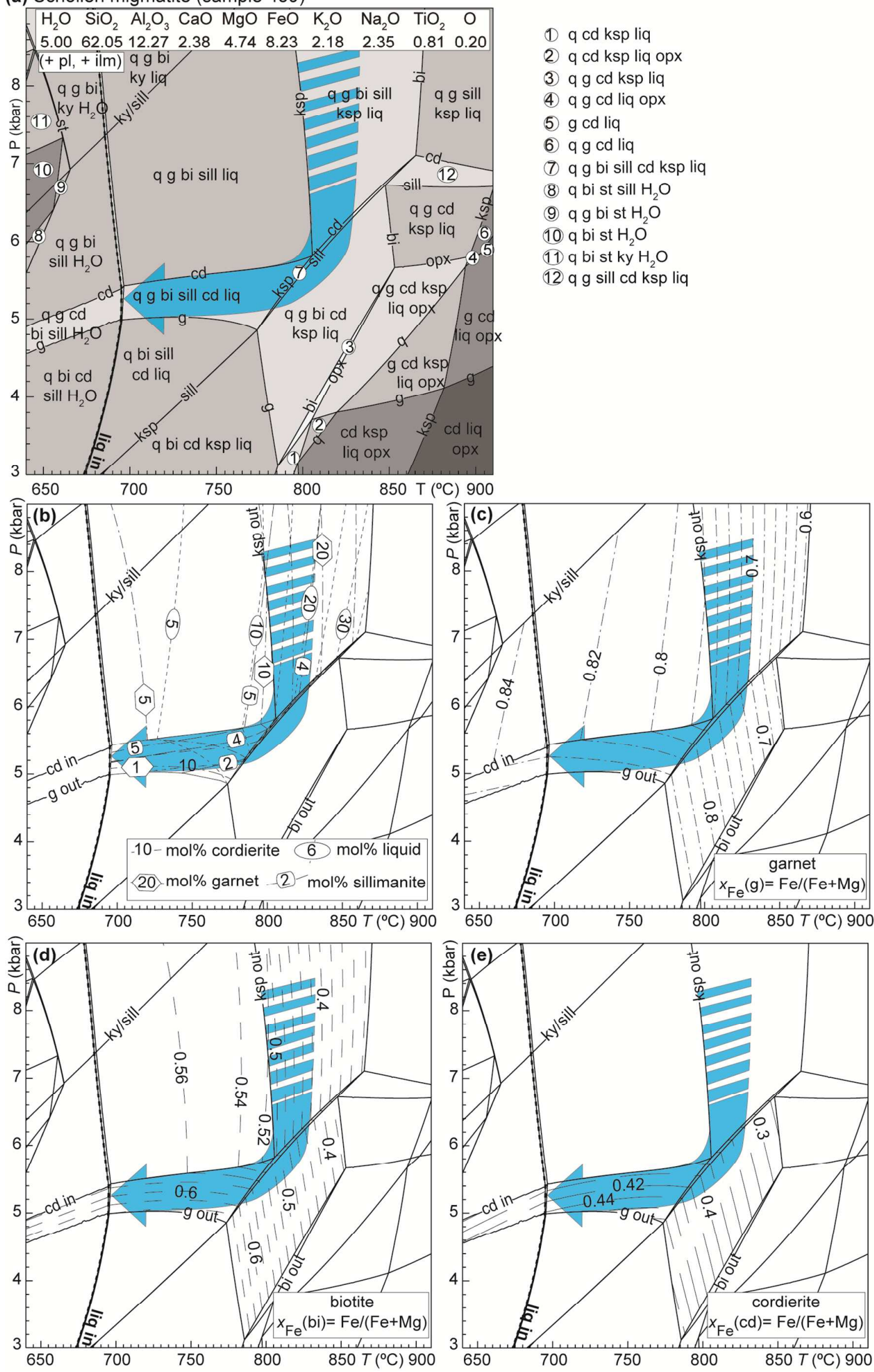

Figure S4. $P-T$ pseudosection (a) calculated in NCKFMASHTO using THERMOCALC for a schollen migmatite (sample 459) with isopleths of molar proportions and mineral compositions for the areas of interest $(\mathrm{b}-\mathrm{e})$. The solidus is underlined by a thick-dashed line. 
(a) Residual melanosome (sample 462)

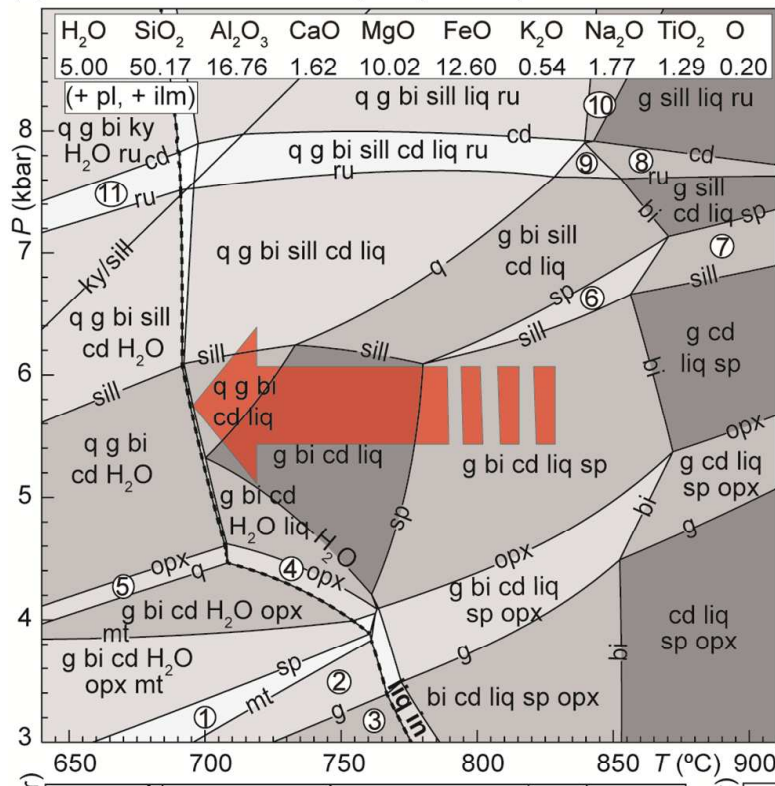

(1) g bi cd $\mathrm{H}_{2} \mathrm{O}$ sp opx mt

(2) $\mathrm{g} \mathrm{bi} \mathrm{cd} \mathrm{H}_{2} \mathrm{O} \mathrm{sp}$ opx

(3) bi cd $\mathrm{H}_{2} \mathrm{O}$ sp opx

(4) $\mathrm{g} \mathrm{bi} \mathrm{cd} \mathrm{H}_{2} \mathrm{O}$ liq opx

(5) q g bi cd $\mathrm{H}_{2} \mathrm{O}$ opx

(6) $\mathrm{g}$ bi sill $c d$ liq $\mathrm{sp}$

(7) $\mathrm{g}$ sill $\mathrm{cd}$ liq $\mathrm{sp}$

(8) g sill cd liq ru

(9) $\mathrm{g}$ bi sill cd liq ru

(10) $q \mathrm{~g}$ sill liq ru

(11) $q \mathrm{~g}$ bi ky cd $\mathrm{H}_{2} \mathrm{O}$ ru
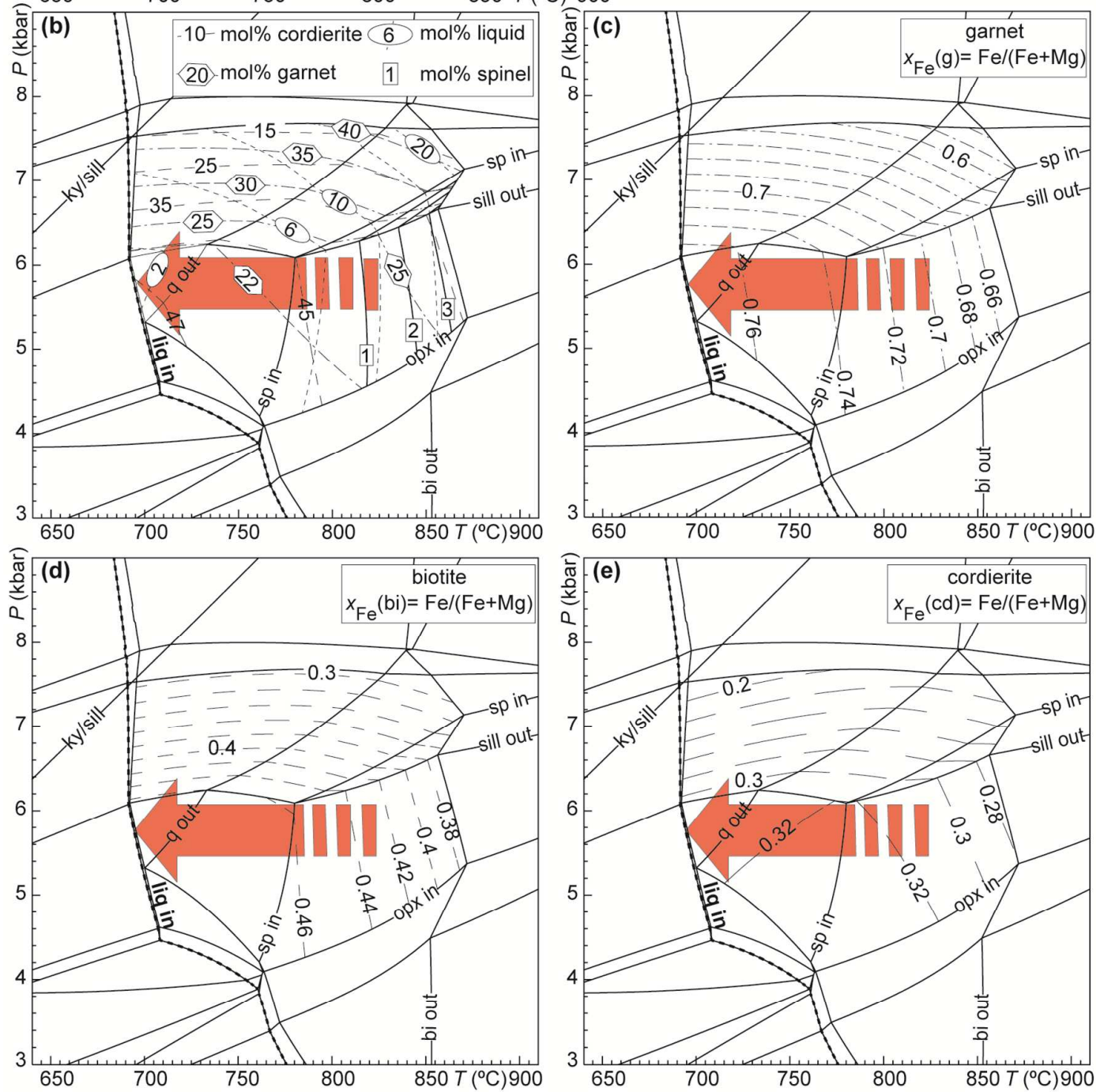

Figure S5. $P-T$ pseudosection (a) calculated in NCKFMASHTO using THERMOCALC for a residual melanosome (sample 462) with isopleths of molar proportions and mineral compositions for the areas of interest $(\mathrm{b}-\mathrm{e})$. The solidus is underlined by a thick-dashed line. 


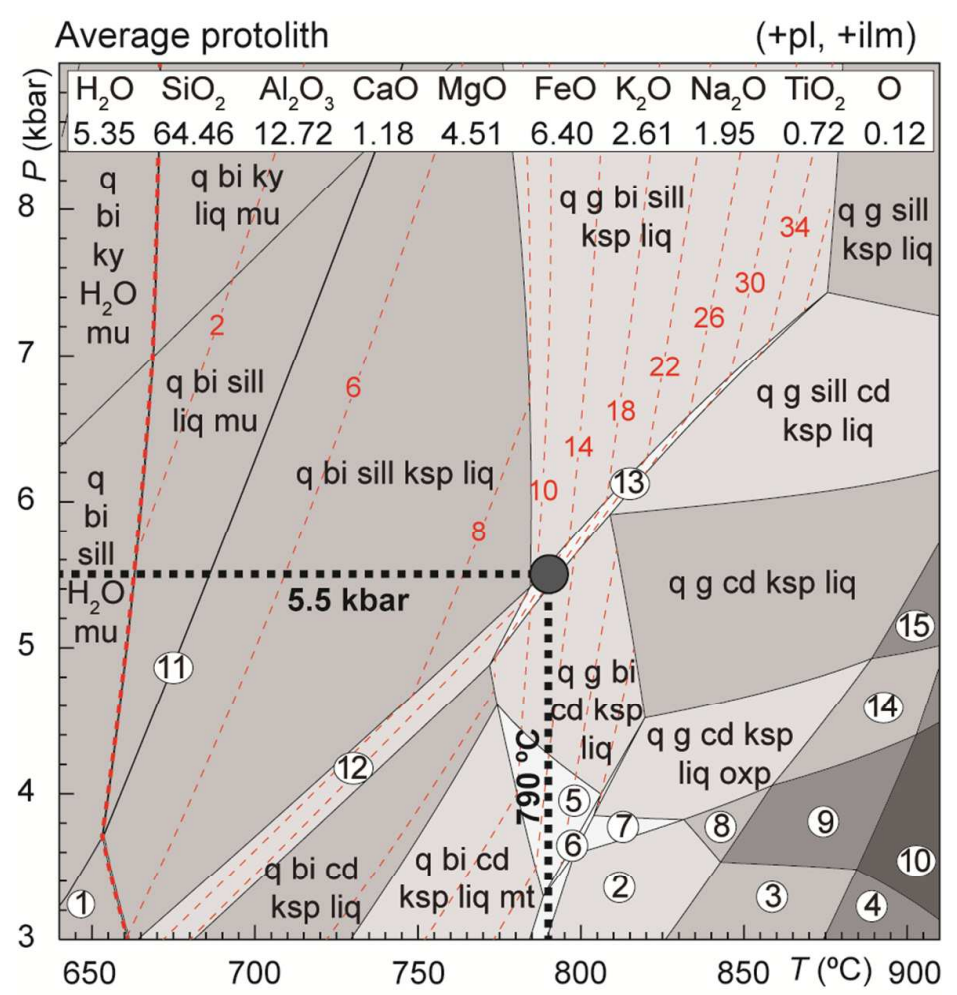
(1) q bi sill ksp $\mathrm{H}_{2} \mathrm{O}$
(8) q cd ksp liq oxp
(2) $q$ cd ksp liq oxp mt
(9) cd ksp liq oxp
(3) cd ksp liq oxp mt
(10) cd liq oxp
(4) cd liq oxp mt
(5) $q \mathrm{~g}$ bi cd ksp liq $\mathrm{mt}$
(11) $q$ bi sill ksp liq mu
(6) $q \mathrm{~g}$ bi cd ksp liq oxp $\mathrm{mt}$
(12) q bi sill cd ksp liq
(7) $\mathrm{q} \mathrm{g} \mathrm{cd} \mathrm{ksp} \mathrm{liq} \mathrm{oxp} \mathrm{mt}$
(13) q g bi sill cd ksp liq
(14) g cd ksp liq oxp
(15) g cd ksp liq

Figure S6. $P-T$ pseudosection calculated in NCKFMASHTO using THERMOCALC for an average protolith with $5.35 \mathrm{~mol} . \% \mathrm{H}_{2} \mathrm{O}$ heating isobarically from $640{ }^{\circ} \mathrm{C}$ (subsolidus) to $790{ }^{\circ} \mathrm{C}$ (suprasolidus). Filled gray circle marks the protolith composition with $14 \mathrm{~mol} . \%$ melt used to construct the melting event diagram (Fig. 8). The molar proportion of liquid is contoured by red dashed lines and the solidus is underlined by a thick red dashed line. 
Table S1. Representative analyses of garnet, biotite and cordierite for the different types of migmatite from the Intermediate series produced by the Ceret gabbro-diorite contact aureole.

\begin{tabular}{|c|c|c|c|c|c|c|c|c|c|c|c|c|c|c|c|c|c|c|}
\hline \multirow{4}{*}{ 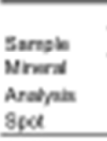 } & \multirow{2}{*}{\multicolumn{4}{|c|}{ 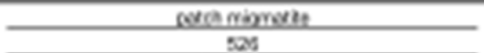 }} & \multirow{2}{*}{\multicolumn{4}{|c|}{ 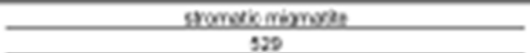 }} & \multirow{2}{*}{\multicolumn{5}{|c|}{ 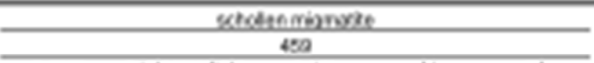 }} & \multirow{2}{*}{\multicolumn{5}{|c|}{ 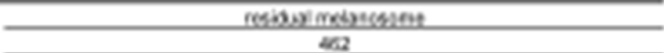 }} \\
\hline & & & & & & & & & & & & & & & & & & \\
\hline & \multirow{2}{*}{ 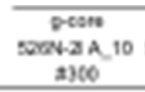 } & \multirow{2}{*}{ 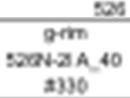 } & \multirow{2}{*}{$\sin _{n=0}=1$} & \multirow{2}{*}{ 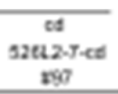 } & \multirow{2}{*}{ 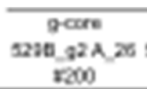 } & \multirow{2}{*}{$\begin{array}{l}\text { oin } \\
\text { cas g2u, } 1 \\
\text { 0175 }\end{array}$} & \multirow{2}{*}{$\begin{array}{c}8 i \\
5202-151 \mathrm{t} \\
203\end{array}$} & \multirow{2}{*}{ 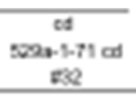 } & \multirow{2}{*}{ 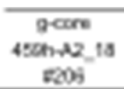 } & \multirow{2}{*}{ 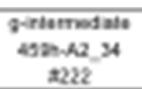 } & g-sin & 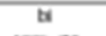 & \multirow{2}{*}{ of } & \multirow{2}{*}{ 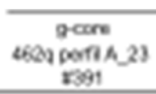 } & \multirow{2}{*}{ 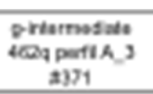 } & \multirow{2}{*}{ 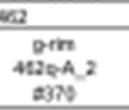 } & \multirow{2}{*}{$\begin{array}{l}81 \\
5 \pi\end{array}$} & \multirow{2}{*}{ ed } \\
\hline & & & & & & & & & & & 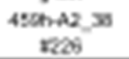 & $450-70$ & & & & & & \\
\hline (MS) & & & & & & & & & & & & & & & & & & \\
\hline 90, & 80.23 & 36.46 & 36.03 & 46.94 & 30.46 & 18 & 56.50 & 49.62 & $36: 54$ & 80.48 & $n, "$ & 3530 & $\Delta 974$ & 3254 & 37.96 & 30.67 & 86.36 & 46.70 \\
\hline no. & ass & 0.02 & 436 & 0.00 & 0.06 & ace & 326 & 0.00 & 0.09 & $a c 8$ & 900 & 258 & 000 & 806 & 007 & $a Q$ & 392 & 0.00 \\
\hline NO, & 21.07 & 20.25 & 1. 2 & נ124 & 21.5 & 21.51 & 17.0 & 297 & 20.45 & 21.24 & 2190 & $20 x$ & 23.10 & 21,12 & 2100 & $21 . \pi$ & 20.46 & 13.91 \\
\hline$F_{\theta 0}$ & 86.20 & 874 & 21,43 & 698 & 30.51 & 34.80 & 17.66 & 7.11 & 36.37 & $86 \pi 1$ & 36.67 & 99.90 & 8.65 & 8911 & 3244 & 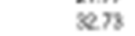 & 1657 & 8.26 \\
\hline Meo & 1.70 & 1.46 & 0.04 & 0.07 & 1.80 & 3.14 & $a \omega$ & 0.28 & 24) & 1.60 & 3.00 & 0.10 & 0.82 & 190 & 074 & 0.60 & $a=0$ & 0.00 \\
\hline $\mathrm{N}_{60}$ & $x 7 t$ & 2.30 & a.11 & a.17 & $6 \pi$ & x:4 & 11.34 & 2.14 & 1.17 & $x>2$ & 222 & 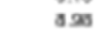 & 780 & 9.72 & 49 & $5 \pi$ & 10.90 & 0.76 \\
\hline 000 & 1,48 & 1.50 & 0.01 & 0.00 & 1.88 & 1.26 & $a, 0$ & 0.09 & 24) & 1.4 & 123 & 0.00 & 000 & 1.97 & .19 & 1.17 & $a 00$ & 0.00 \\
\hline Nasoo & ase & 0.96 & 0.93 & 0.23 & 0.00 & $a c e$ & $0.2 \%$ & 0.24 & 605 & $a 00$ & 900 & 0.34 & 0.34 & 890 & 000 & $a c e$ & 0.26 & 0.19 \\
\hline $\mathrm{K}, \mathrm{O}$ & 0.00 & 0.00 & 0.71 & 0.00 & 0.0 & 0.00 & 200 & 0.00 & 0.00 & 0.00 & 0.09 & 25 & 000 & 0.00 & $\infty$ & 0.00 & $T H$ & 0.00 \\
\hline Tus & 160.47 & 160.40 & $96 \%$ & 9624 & 10072 & 101.50 & $\$ 6.86$ & 99.39 & 9695 & 101.67 & 101.95 & 9.17 & 9920 & noos & 10400 & 100.67 & se. 10 & $\$ 4.41$ \\
\hline axpon & 12 & 12 & 11 & u & 12 & 12 & 11 & to & 12 & 12 & 12 & "1 & to & 12 & 12 & 12 & 11 & 10 \\
\hline si & $2 n$ & $2 x$ & 2.74 & 504 & 200 & 201 & $2 \pi 0$ & 49 & $2.9 n$ & $2 x$ & 200 & 2.74 & 497 & $2.2 n$ & 200 & $2 x$ & 27 & 4.24 \\
\hline$\pi$ & ase & 0.00 & 0.24 & 600 & 000 & ase & 0.19 & 0.00 & 0.01 & $a 60$ & 800 & 0.16 & 000 & 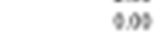 & $0 \omega$ & 0,6 & Q.18 & 0.06 \\
\hline A) & 1.96 & 1.94 & $1 ., 65$ & 3.84 & 200 & 200 & 1.62 & 397 & 201 & 201 & 200 & 18 & 356 & $29 n$ & 190 & 206 & 1.86 & 4.96 \\
\hline$r_{0}$ & 0.07 & 0.00 & 0.00 & 0.00 & 0.01 & 0.00 & 0.00 & 0.16 & 0.02 & ace & 0.97 & $0 \infty$ & Q.14 & 0.04 & Q.11 & $0.0 \%$ & 0.00 & 0.16 \\
\hline $\mathrm{Fa}^{\mathrm{in}}$ & 228 & 2.44 & 1.4: & 6.99 & 1.66 & 286 & 1.16 & 0.45 & 247 & 2.36 & 2.37 & 122 & 062 & 2.15 & 200 & 206 & 1.96 & 0.54 \\
\hline Mo & 0.11 & 2.11 & 0.01 & 0.01 & 0.12 & a.21 & $a 06$ & 0.02 & 0.97 & 0.11 & 820 & 0.01 & 200 & 8.97 & 0.05 & 0.04 & 0.0 & 0.00 \\
\hline$M_{0}$ & 0.45 & 0.26 & 0.25 & 1.25 & ar & 0.42 & 1.31 & 13 & 0.4 & 0.30 & 027 & 100 & 2.19 & 0.47 & 000 & $a \pi$ & 1.23 & 1.22 \\
\hline Co & 0.18 & 0.18 & 0.09 & 0.00 & a."1 & 0.11 & $a 00$ & 0.00 & 0.21 & a.17 & a"1 & 0.00 & 000 & 0.99 & 0.10 & 0.10 & 0.00 & 0.00 \\
\hline No & aso & 0.00 & 0.02 & 0.05 & 0.00 & $a c 0$ & $a 04$ & 0.05 & 0.00 & $a 00$ & 0.00 & 0.06 & 207 & 9.90 & 000 & 0.60 & 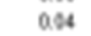 & 0.04 \\
\hline K & 0.00 & 0.60 & Q.97 & 0.00 & 0.00 & 0.00 & 0.20 & 0.09 & 0.00 & 0.00 & 0.09 & 0.9 & $0 \infty 0$ & 0.00 & $0, \infty$ & 0.00 & 0.70 & 0.00 \\
\hline ceters & 800 & 8.00 & 802 & 11.00 & 800 & 806 & 860 & 1100 & 805 & 806 & 800 & 8.00 & 1160 & 800 & 799 & 7.64 & 7.97 & 11.00 \\
\hline 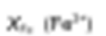 & 0.04 & 0.90 & 0.00 & Sas & בת & out & 0.47 & 0.24 & 0.25 & a.s & $0 x$ & 0.54 & $a \times 4$ & 0.70 & a & an & 0.47 & 0.20 \\
\hline$x_{\infty}$ I Foxes & a.s & 0.90 & 69 & 6.34 & 072 & $a, 4$ & a. & 0.31 & 0.95 & 0.66 & (9.9) & 0.54 & 0.39 & 0.74 & $0 \pi 1$ & 0.74 & 0.47 & 0.36 \\
\hline an & $a n$ & 0.98 & & & 0.6 & 076 & & & 0.83 & a.8 & 0.81 & & & 0.72 & 069 & $a>0$ & & \\
\hline inp & 0.15 & 0.60 & & & $02 x$ & Q.14 & & & 0.05 & Q.13 & om & & & 0.22 & 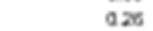 & 0.25 & & \\
\hline on & 0.04 & 0.04 & & & 0.04 & 0.04 & & & 0.97 & ace & 0.04 & & & 0.03 & 000 & 0.03 & & \\
\hline ss & a.s & 0.04 & & & 0.06 & $a, 0$ & & & 0.06 & $a 04$ & 9.97 & & & 8.92 & 000 & aOA & & \\
\hline
\end{tabular}


Table S2. Representative whole-rock chemical analyses (in wt.\%) of the different types of migmatite and non-migmatitic rocks from the Roc de Frausa Massif. Molar fractions: A/CNK:

$\mathrm{Al}_{2} \mathrm{O}_{3} /\left(\mathrm{CaO}+\mathrm{Na}_{2} \mathrm{O}+\mathrm{K}_{2} \mathrm{O}\right) ; \mathrm{A} / \mathrm{AFMT}: \mathrm{Al}_{2} \mathrm{O}_{3} /\left(\mathrm{Al}_{2} \mathrm{O}_{3}+\mathrm{FeO}+\mathrm{MgO}+\mathrm{TiO}_{2}\right) ; \mathrm{A} / \mathrm{AKN}$ :

$\mathrm{Al}_{2} \mathrm{O}_{3} /\left(\mathrm{Al}_{2} \mathrm{O}_{3}+\mathrm{K}_{2} \mathrm{O}+\mathrm{Na}_{2} \mathrm{O}\right) ; X_{\mathrm{Si}}: \mathrm{SiO}_{2} /\left(\mathrm{SiO}_{2}+\mathrm{Al}_{2} \mathrm{O}_{3}+\mathrm{FeO}+\mathrm{MgO}+\mathrm{TiO}_{2}\right) ; X_{\mathrm{Fe}}: \mathrm{FeO} /(\mathrm{FeO}+\mathrm{MgO})$.

Average protolith: hypothetical composition of the protolith of migmatites.

\begin{tabular}{|c|c|c|c|c|c|c|c|c|}
\hline \multirow{2}{*}{$\begin{array}{l}\text { Rock type } \\
\text { sample }\end{array}$} & \multirow{2}{*}{$\begin{array}{r}\text { patch } \\
526 \\
\end{array}$} & \multicolumn{4}{|c|}{ stromatic migmaites } & \multicolumn{2}{|c|}{ schollen } & \multirow{2}{*}{$\begin{array}{r}\text { residua } \\
453 \\
\end{array}$} \\
\hline & & 416 & 460 & 472 & 529 & 459 & 471 & \\
\hline (wt.\%) & & & & & & & & \\
\hline $\mathrm{SiO}_{2}$ & 52.40 & 61.55 & 63.71 & 61.15 & 57.60 & 56.77 & 50.17 & 47.51 \\
\hline $\mathrm{TiO}_{2}$ & 1.71 & 1.09 & 1.18 & 0.85 & 1.04 & 0.98 & 1.18 & 1.23 \\
\hline $\mathrm{Al}_{2} \mathrm{O}_{2}$ & 19.76 & 19.53 & 16.69 & 15.19 & 17.75 & 19.04 & 19.71 & 24.48 \\
\hline $\mathrm{FeO}_{1}$ & 10.42 & 7.42 & 8.31 & 6.04 & 7.90 & 9.00 & 8.73 & 10.40 \\
\hline $\mathrm{MnO}$ & 0.11 & 0.06 & 0.05 & 0.08 & 0.12 & 0.13 & 0.15 & 0.10 \\
\hline $\mathrm{MgO}$ & 3.19 & 1.97 & 2.31 & 3.71 & 4.68 & 2.91 & 4.71 & 4.58 \\
\hline $\mathrm{CaO}$ & 3.53 & 0.14 & 0.43 & 2.39 & 2.75 & 2.03 & 1.15 & 1.25 \\
\hline $\mathrm{Na}_{2} \mathrm{O}$ & 1.29 & 0.92 & 0.81 & 2.54 & 2.26 & 2.22 & 1.44 & 1.57 \\
\hline $\mathrm{K}_{2} \mathrm{O}$ & 3.52 & 3.43 & 2.25 & 2.40 & 2.86 & 3.12 & 5.66 & 2.19 \\
\hline $\mathrm{P}_{2} \mathrm{O}_{3}$ & 0.25 & 0.06 & 0.07 & 0.24 & 0.22 & 0.11 & 0.42 & 0.10 \\
\hline L.O.I. & 2.08 & 1.42 & 2.51 & 1.93 & 1.68 & 1.42 & 2.64 & 2.70 \\
\hline Total & 98.25 & 97.57 & 98.30 & 96.49 & 98.83 & 97.72 & 95.94 & 96.08 \\
\hline \multicolumn{9}{|l|}{$(m o l . \%)$} \\
\hline $\mathrm{K}_{2} \mathrm{O} / \mathrm{Na}_{2} \mathrm{O}$ & 1.80 & 2.45 & 1.83 & 0.62 & 0.83 & 0.93 & 2.60 & 0.92 \\
\hline $\mathrm{A} / \mathrm{CN}$ & 1.60 & 3.57 & 3.67 & 1.37 & 1.51 & 1.78 & 1.86 & 3.39 \\
\hline $\mathrm{CaO} / \mathrm{Na}_{2} \mathrm{O}$ & 3.04 & 0.16 & 0.59 & 1.04 & 1.35 & 1.01 & 0.89 & 0.88 \\
\hline AVAFMT & 0.44 & 0.54 & 0.47 & 0.44 & 0.42 & 0.47 & 0.43 & 0.47 \\
\hline A/AKN & 0.77 & 0.79 & 0.82 & 0.69 & 0.72 & 0.73 & 0.70 & 0.83 \\
\hline$x_{s}$ & 0.66 & 0.74 & 0.75 & 0.75 & 0.70 & 0.70 & 0.65 & 0.61 \\
\hline$x_{r .}$ & 0.65 & 0.68 & 0.67 & 0.48 & 0.49 & 0.63 & 0.51 & 0.56 \\
\hline \multirow{2}{*}{$\begin{array}{l}\text { Rock type } \\
\text { sample }\end{array}$} & \multicolumn{7}{|c|}{ non-migmatitic rocks } & average \\
\hline & 187 & 237 & 338 & 412 & 523 & 525 & 528 & $\overline{\text { protolith }}$ \\
\hline$\overline{\text { (wt.\%) }}$ & & & & & & & & \\
\hline $\mathrm{SiO}_{2}$ & 55.58 & 63.88 & 61.00 & 57.52 & 54.89 & 58.90 & 59.90 & 58.81 \\
\hline $\mathrm{TiO}_{2}$ & 0.94 & 0.80 & 0.91 & 1.00 & 0.82 & 0.82 & 0.93 & 0.89 \\
\hline $\mathrm{Al}_{2} \mathrm{O}$, & 21.77 & 16.23 & 19.51 & 21.40 & 21.02 & 20.07 & 20.12 & 20.02 \\
\hline $\mathrm{FeO}$, & 7.81 & 6.09 & 6.52 & 7.33 & 7.98 & 6.56 & 7.03 & 7.05 \\
\hline $\mathrm{MnO}$ & 0.07 & 0.08 & 0.07 & 0.09 & 0.11 & 0.06 & 0.08 & 0.08 \\
\hline $\mathrm{MgO}$ & 2.90 & 2.82 & 2.43 & 2.56 & 3.29 & 2.74 & 2.42 & 2.74 \\
\hline $\mathrm{CaO}$ & 0.85 & 1.27 & 1.05 & 1.23 & 0.94 & 0.76 & 0.82 & 0.99 \\
\hline $\mathrm{Na}_{2} \mathrm{O}$ & 1.82 & 2.50 & 1.78 & 1.91 & 2.03 & 1.77 & 1.03 & 1.83 \\
\hline $\mathrm{K}_{2} \mathrm{O}$ & 3.51 & 3.37 & 4.08 & 4.16 & 3.72 & 3.46 & 4.06 & 3.76 \\
\hline $\mathrm{P}_{2} \mathrm{O}_{6}$ & 0.13 & 0.21 & 0.13 & 0.14 & 0.18 & 0.14 & 0.16 & 0.15 \\
\hline L.o.I. & 3.95 & 2.25 & 2.28 & 2.11 & 4.14 & 3.89 & 2.88 & 3.07 \\
\hline Total & 99.31 & 99.48 & 99.73 & 99.42 & 99.09 & 99.14 & 99.41 & 99.37 \\
\hline \multicolumn{9}{|l|}{ (mol.\%) } \\
\hline $\mathrm{K}_{2} \mathrm{O} / \mathrm{Na}_{2}$ & 1.27 & 0.89 & 1.51 & 1.43 & 1.21 & 1.29 & 2.61 & 1.46 \\
\hline $\mathrm{A} / \mathrm{CNK}$ & 2.62 & 1.61 & 2.11 & 2.17 & 2.32 & 2.50 & 2.66 & 2.28 \\
\hline $\mathrm{CaO} / \mathrm{Na}_{2} \mathrm{O}$ & 0.51 & 0.56 & 0.65 & 0.71 & 0.51 & 0.47 & 0.88 & 0.62 \\
\hline AVAFMT & 0.53 & 0.49 & 0.54 & 0.54 & 0.50 & 0.54 & 0.54 & 0.53 \\
\hline ANAKN & 0.76 & 0.68 & 0.73 & 0.74 & 0.74 & 0.75 & 0.77 & 0.74 \\
\hline$x_{3}$ & 0.69 & 0.77 & 0.74 & 0.71 & 0.69 & 0.73 & 0.73 & 0.72 \\
\hline$X_{F}$ & 0.60 & 0.55 & 0.60 & 0.62 & 0.58 & 0.57 & 0.62 & 0.59 \\
\hline
\end{tabular}


Table S3. Residue and anatectic melt bulk compositions calculated at $5.5 \mathrm{kbar}$. The residue compositions are calculated for the seven melting episodes (R1-R7). Anatectic melt compositions correspond to those of the solidus for a patch migmatite (sample 526; Fig. S2), a stromatic migmatite (sample 529; Fig. S3), a schollen migmatite (sample 459; Fig. S4) and a residual melanosome (sample 462; Fig. S5).

\begin{tabular}{lrrrrrrrrrrr}
\hline & $\mathrm{T}\left({ }^{\circ} \mathrm{C}\right)$ & $\mathrm{H}_{2} \mathrm{O}$ & $\mathrm{SiO}_{2}$ & $\mathrm{Al}_{2} \mathrm{O}_{2}$ & $\mathrm{CaO}$ & $\mathrm{MgO}$ & $\mathrm{FeO}$ & $\mathrm{K}_{2} \mathrm{O}$ & $\mathrm{Na}_{2} \mathrm{O}$ & $\mathrm{TiO}_{2}$ & $\mathrm{O}$ \\
\hline residue R1 & 790 & 3.44 & 63.92 & 13.50 & 1.31 & 5.24 & 7.37 & 2.50 & 1.75 & 0.84 & 0.14 \\
residue R2 & 790 & 4.36 & 59.71 & 14.39 & 1.50 & 6.43 & 8.94 & 2.15 & 1.32 & 1.03 & 0.17 \\
residue R3 & 790 & 4.70 & 55.52 & 15.46 & 1.69 & 7.77 & 10.70 & 1.76 & 0.93 & 1.25 & 0.21 \\
residue R4 & 790 & 5.01 & 52.10 & 16.33 & 1.83 & 8.84 & 12.11 & 1.43 & 0.68 & 1.43 & 0.24 \\
residue R5 & 790 & 5.21 & 49.36 & 17.06 & 1.93 & 9.71 & 13.25 & 1.16 & 0.50 & 1.57 & 0.26 \\
residue R6 & 790 & 5.17 & 47.12 & 17.73 & 2.00 & 10.46 & 14.23 & 0.95 & 0.37 & 1.70 & 0.29 \\
residue R7 & 790 & 5.46 & 46.34 & 17.84 & 2.01 & 10.65 & 14.47 & 0.90 & 0.30 & 1.73 & 0.29 \\
Anatectic melt 526 & 722 & 30.21 & 57.65 & 6.30 & 0.27 & 0.07 & 0.26 & 1.14 & 4.11 & 0.00 & 0.00 \\
Anatectic melt 529 & 712 & 29.91 & 57.91 & 6.06 & 0.35 & 0.18 & 0.47 & 0.92 & 4.20 & 0.00 & 0.00 \\
Anatectic melt 459 & 695 & 28.72 & 59.36 & 6.26 & 0.55 & 0.10 & 0.35 & 1.75 & 2.90 & 0.00 & 0.00 \\
Anatectic melt 462 & 697 & 30.40 & 57.37 & 6.17 & 0.24 & 0.13 & 0.35 & 0.85 & 4.50 & 0.00 & 0.00 \\
\hline
\end{tabular}


Table S4. Representative whole-rock compositions of the Ceret gabbro-diorite stock and a leucogranite from the Sant Llorenç-La Jonquera pluton.

\begin{tabular}{|c|c|c|c|}
\hline Igneous rock type & diorite & gabbro & leucogranite \\
\hline Sample & 420 & 419 & 215 \\
\hline \multicolumn{4}{|l|}{$(w t . \%)$} \\
\hline $\mathrm{SiO}_{2}$ & 46.56 & 51.88 & 74.26 \\
\hline $\mathrm{TiO}_{2}$ & 0.70 & 1.16 & 0.08 \\
\hline $\mathrm{Al}_{2} \mathrm{O}_{3}$ & 14.44 & 17.81 & 13.97 \\
\hline $\mathrm{Fe}_{2} \mathrm{O}_{3}$ & 22.66 & 9.53 & 0.84 \\
\hline $\mathrm{MnO}$ & 0.30 & 0.13 & 0.03 \\
\hline $\mathrm{MgO}$ & 2.78 & 4.99 & 0.16 \\
\hline $\mathrm{CaO}$ & 5.08 & 8.09 & 0.89 \\
\hline $\mathrm{Na}_{2} \mathrm{O}$ & 2.93 & 2.58 & 3.59 \\
\hline $\mathrm{K}_{2} \mathrm{O}$ & 1.12 & 1.64 & 4.89 \\
\hline $\mathrm{P}_{2} \mathrm{O}_{5}$ & 0.00 & 1.08 & 0.90 \\
\hline L.O.I & 0.35 & 0.23 & 0.27 \\
\hline Total & 96.92 & 99.12 & 99.88 \\
\hline \multicolumn{4}{|l|}{ (mol.\%) } \\
\hline $\mathrm{K}_{2} \mathrm{O} / \mathrm{Na}_{2} \mathrm{O}$ & 0.38 & 0.64 & 1.36 \\
\hline AVCNK & 0.95 & 0.86 & 1.09 \\
\hline $\mathrm{CaO} / \mathrm{Na}_{2} \mathrm{O}$ & 1.92 & 3.47 & 0.27 \\
\hline AVAFMT & 0.28 & 0.40 & 0.90 \\
\hline A/AKN & 0.71 & 0.75 & 0.56 \\
\hline $\mathrm{X}_{\mathrm{s}}$ & 0.61 & 0.67 & 0.89 \\
\hline$\underline{X_{f s}}$ & 0.80 & 0.49 & 0.73 \\
\hline
\end{tabular}

